\title{
OPEN Evaluation of potential miticide toxicity to Varroa destructor and honey bees, Apis mellifera, under laboratory conditions
}

\author{
Rassol Bahreini $^{凶}$, Medhat Nasr, Cassandra Docherty, Olivia de Herdt, Samantha Muirhead \& \\ David Feindel
}

The honey bee, Apis mellifera L., is the world's most important managed pollinator of agricultural crops, however, Varroa mite, Varroa destructor Anderson and Trueman, infestation has threatened honey bee survivorship. Low efficacy and development of Varroa mite resistance to currently used Varroacides has increased the demand for innovative, effective treatment tool options that exhibit high efficacy, while minimizing adverse effects on honey bee fitness. In this investigation, the toxicity of 16 active ingredients and 9 formulated products of registered miticides for use on crops from 12 chemical families were evaluated in comparison to amitraz on Varroa mites and honey bees using contact surface and topical exposures. It was found that fenpyroximate ( $93 \%$ mortality), spirotetramat ( $84 \%$ mortality) and spirodiclofen $(70 \%$ mortality) had greater toxicity to Varroa mites, but high dose rates caused high bee mortality $(>60 \%)$. With this in mind, further research is needed to investigate other options to minimize the adverse effect of these compounds on bees. The results also found high toxicity of fenazaquin and etoxazole against Varroa mites causing $92 \%$ and $69 \%$ mortality, respectively; and were found to be safe on honey bees. Collectively, it is recommended that fenazaquin and etoxazole are candidates for a potential Varroacide and recommended for further testing against Varroa mites at the colony level.

In recent years, managed honey bees, Apis mellifera L., have had numerous health threats, which has resulted in losing a significantly higher annual loss of bee colonies averaging $30 \%$ or more when compared to long-term historical averages $(15 \%)^{1,2}$. Although beekeepers are able to recoup their annual losses through colony management in the spring and summer, persistent high losses have made it more difficult and expensive to rebuild colony numbers. At the same time, high costs of buying bee packages or bees to replace dead outs, availability of healthy bees, increased cost of pest and disease management and unexpected business interruptions have created an unsustainable financial burden for beekeepers. In Canada ${ }^{1}$ and the USA ${ }^{2}$ bee colony losses were attributed to: bee parasitization by Varroa mites ${ }^{3}$, Varroa destructor Anderson and Trueman, Nosema spp. ${ }^{4}$, viruses ${ }^{5}$, poor nutrition ${ }^{6}$, and pesticides ${ }^{7}$. Varroa mites have been identified as the single most serious cause of colony loss and are considered the most prevalent honey bee pest in the world ${ }^{8}$. As an ectoparasite, Varroa mite threatens bee colony health by feeding on the fat bodies of immature and mature bees ${ }^{9}$. This weakens their immune system, uses the nutrient reserves required for overwintering in cold climates, and transmits viruses. The struggle to maintain the health of honey bees in the wake of $V$. destructor has resulted in the need to develop mite control options and to implement an integrated pest management approach that benefits beekeepers ${ }^{10}$. Tactics such as the use of genetically tolerant bees, cultural practices, and chemical control methods such as essential oils, organic acids, and synthetic miticides, are considered for mite management. Synthetic Varroacides, such as pyrethroids, organophosphate and formamidine, have been used to control Varroa mite populations globally, since the 1980's. The long-term use of these products has led to the development of resistance in mite populations, the accumulation of residues in bee products, and an increased risk to human health ${ }^{11-13}$. Currently, populations of Varroa mites globally have developed resistance to the pyrethroid, Apistan (824 mg of tau-fluvalinate/strip, Vita Europe), and to the organophosphate, Checkmite (1300 mg coumaphos/strip, Bayer) ${ }^{1}$. Additionally, resistance is emerging to the only remaining viable formamidine miticide, Apivar (500 mg of amitraz/strip, Veto Pharma $)^{12}$. This new reality highlights the need for alternative synthetic products with different modes of action, which would 
support an integrated approach to the management of mites and maintenance of healthy bees. In an attempt to manage resistance to synthetic miticides, organic acids such as formic acid, oxalic acid and essential oil-based miticides have been used in rotation; however, mite control has been variable. The reluctance of beekeepers to use organic acid and essential oil-based miticides has led to an increased reliance on synthetic miticides. Therefore, it is imperative to find new active ingredients (AIs) with modes of action different from currently available miticides that will selectively kill Varroa mites without harming honey bees.

Pesticide resistance testing from other insect species can be adapted to test novel chemicals on Varroa mites and honey bees. Plapp et al. ${ }^{14}$ initially developed a glass vial method to evaluate the presence of pesticide resistance in the tobacco budworm moth, Heliothis virescens (F.) in cotton. In this technique, synthetic miticides were dissolved in a solvent and applied to cover the inner surface of $20 \mathrm{~mL}$ borosilicate glass scintillation vials. This method was also used for determining the resistance or toxicity of chemicals against red-legged earth mites ${ }^{15}$, Halotydeus destructor (Tucker), two spotted spider mites ${ }^{16}$, Tetranychus urticae Koch, silverleaf whiteflies ${ }^{17}$, Bemisia argentifolii Bellows and Perring, plant bugs ${ }^{18}$, Thrips ${ }^{19}$, as well Varroa mites ${ }^{20-22}$. In this study, a modified glass vial technique was adopted form miticide screening ${ }^{22}$ and Varroa resistance ${ }^{23}$ studies. Determining the median lethal concentration $\left(\mathrm{LC}_{50}\right)$, dose $\left(\mathrm{LD}_{50}\right)$ and mortality rates of Varroa mites and honey bees to candidate compounds using bioassay techniques are standard approaches for evaluating the efficacy and toxicity of miticides on animals. These methods are also used to monitor the degree of resistance in Varroa mite populations. Vandervalk ${ }^{22}$ found high toxicity when exposing Varroa mites to acequinocyl followed by clofentezine, spiromesifen and bifenazate using the glass vial technique. Ali et al. ${ }^{24}$ reported a high mite mortality for tebufenpyrad, however, this product exhibited a high bee mortality. Fenpyroximate caused significantly higher mortality in queens (at $9.7 \mu \mathrm{g} /$ queen), compared to worker bees ${ }^{25}$, but according Leite et al. ${ }^{26}$, fenpyroximate at $1000 \mathrm{mgL}^{-1}$ was safe for bees. Recently, based on an RNAi method, Ziegelman et al. ${ }^{27}$ found that lithium chloride used to precipitate RNA was effective at controlling Varroa mites under laboratory conditions. The study demonstrated that $10.6 \mu \mathrm{g}$ of lithium chloride fed to bees killed $100 \%$ of mites during a $48 \mathrm{~h}$ observation. Maggi et al. ${ }^{28}$ reported the $\mathrm{LC}_{50}$ for susceptible Varroa mite population in Argentina $(0.1 \mu \mathrm{g} / \mathrm{dish})$. In Canada, amitraz is one of the most commonly used in-hive miticides, however, the $\mathrm{LC}_{50}$ baseline levels for amitraz and other Varroacides, for susceptible and resistant Varroa mite populations, have not been determined.

The objective of this investigation was to develop laboratory bioassay techniques for the screening of potential miticides against $V$. destructor, and to determine the toxicity of 16 miticidal AIs and 9 commercially available formulated miticidal products (FPs) from 12 different chemical families in comparison to amitraz to $V$. destructor and A. mellifera (Supplementary Table S1).

\section{Results}

Solvent, reference and death controls. Acetone, acetonitrile and water were chosen as solvents in the pre-test for making dilutions, and tested as solvent controls for AIs and FPs, respectively. Acetonitrile was used as a specific solvent for clofentezine; however, other AIs $(n=16)$ were dissolved in acetone to make a stock solution. All FPs $(n=10)$ were diluted in water. The solvents did not have a significant influence on mite or bee mortality, with the exception of acetonitrile which resulted in a higher mite and bee mortality (5-35\%) compared to other solvents (0-11\%) (Supplementary Table S2). Amitraz and Mitaban were used as reference control for AIs and FPs, respectively. Amitraz killed $\geq 90 \%$ of Varroa mites when the mites were exposed to a dilution of $\geq 10$ $\mathrm{mgL}^{-1}$ in surface contact (glass vial) $(\mathrm{F}=40.67 ; \mathrm{df}=6,21 ; \mathrm{p}<0.0001)$; or $\geq 68 \%$ in dilution $\geq 0.000117 \mu \mathrm{g} / \mathrm{mite}$ in topical (micro-applicator) $(\mathrm{F}=756.89 ; \mathrm{df}=6,21 ; \mathrm{p}<0.0001)$ methods. Mitaban, however, achieved $>32 \%$ mite mortality at $\geq 1000 \mathrm{mgL}^{-1}$, significantly higher than other FPs and the control $(\mathrm{F}=8.61 ; \mathrm{df}=5,18 ; \mathrm{p}=0.0003)$. Amitraz was safe on newly-emerged worker bees when treated with $\leq 100 \mathrm{mgL}^{-1}$ by surface contact (Mason jar) $(\mathrm{F}=18.91 ; \mathrm{df}=6,21 ; \mathrm{p}<0.0001)$, or $\leq 0.78 \mu \mathrm{g} /$ bee by topical applications $(\mathrm{F}=43.96 ; \mathrm{df}=6,28 ; \mathrm{p}<0.0001)$. In the surface contact method, Mitaban in dilution $\leq 0.1 \mathrm{mgL}^{-1}$ killed $\geq 76 \%$ bees $(\mathrm{F}=86.95 ; \mathrm{df}=6,27 ; \mathrm{p}<0.0001)$, compared to $\leq 3 \%$ mortality at $\leq 0.78 \mu \mathrm{g} /$ bee in topical applications $(\mathrm{F}=2.31 ; \mathrm{df}=6,27 ; \mathrm{p}=0.0629)$ (Supplementary Tables S3, S4). In the investigation, dimethoate $\left(0.000033 \mathrm{mgL}^{-1}\right)$ and amitraz $\left(100,000 \mathrm{mgL}^{-1}\right)$ were used as death controls to verify the sensitivity of $A$. mellifera and $V$. destructor to selected compounds, respectively. Both treatments resulted in $100 \%$ mortality of bees and mites. Thus, mortality variables of dimethoate and amitraz dilution of $100,000 \mathrm{mgL}^{-1}$ were removed from the statistical analyses.

Toxicity assay on Varroa mites. AIs surface contact toxicity assay. AIs $(\mathrm{n}=17)$ were tested to determine the surface contact toxicity on Varroa mites by coating the AIs on the inner surface of glass vials. Initial results show high variability in toxicity after $4 \mathrm{~h}$ exposure $(\mathrm{F}=25.92 ; \mathrm{df}=17,393 ; \mathrm{p}<0.0001)$ (Fig. 1). The highest cumulative mortalities were recorded when mites were exposed to fenazaquin $(76.4 \pm 5.2 \%)$, tebufenpyrad $(73.7 \pm 5.3 \%)$ and fenpyroximate $(63.6 \pm 5.2 \%)$ compared to the reference control, amitraz $(55.1 \pm 5.2 \%)$. At $4 \mathrm{~h}$ exposure, cumulative mite mortality for fenpropathrin $(57.6 \pm 5.2 \%)$, pyridaben $(51.4 \pm 5.2 \%)$ and tolfenpyrad $(51 \pm 5.2 \%)$ treatment were not significantly different from amitraz. However, after $24 \mathrm{~h}$ post exposure, cumulative mite mortality was greatest for bifenthrin $(94.3 \pm 3.5 \%)$, fenpyroximate $(93.2 \pm 2.5 \%)$, fenazaquin $(92.3 \pm 4.3 \%)$, tebufenpyrad $(91.2 \pm 4.5 \%)$, chlorfenapyr $(88.9 \pm 3.1 \%)$ and abamectin $(88.9 \pm 3.1 \%)$. All AIs listed above had significantly higher cumulative mite mortality, compared to amitraz $(76.6 \pm 4.3 \%)$ and others AIs $(\mathrm{F}=31.49 ; \mathrm{df}=17,388 ; \mathrm{p}<0.0001)$ (Fig. 2). Results also showed a relatively low cumulative mite mortality for clofentezine after $4 \mathrm{~h}(8.8 \pm 5.2 \%)$ exposure or after $24 \mathrm{~h}(61.5 \pm 3.1 \%)$ post-treatment in comparison to amitraz. In this case, mite mortality was likely attributed to the solvent acetonitrile (Supplementary Table S2).

FPs surface contact toxicity assay. In the glass vial test, cumulative mite mortality varied among FPs $(\mathrm{n}=10)$ after the $4 \mathrm{~h}$ exposure $(\mathrm{F}=12.09 ; \mathrm{df}=10,266 ; \mathrm{p}<0.0001)$ and $24 \mathrm{~h}(\mathrm{~F}=37.79 ; \mathrm{df}=10,266 ; \mathrm{p}<0.0001)$ post- 


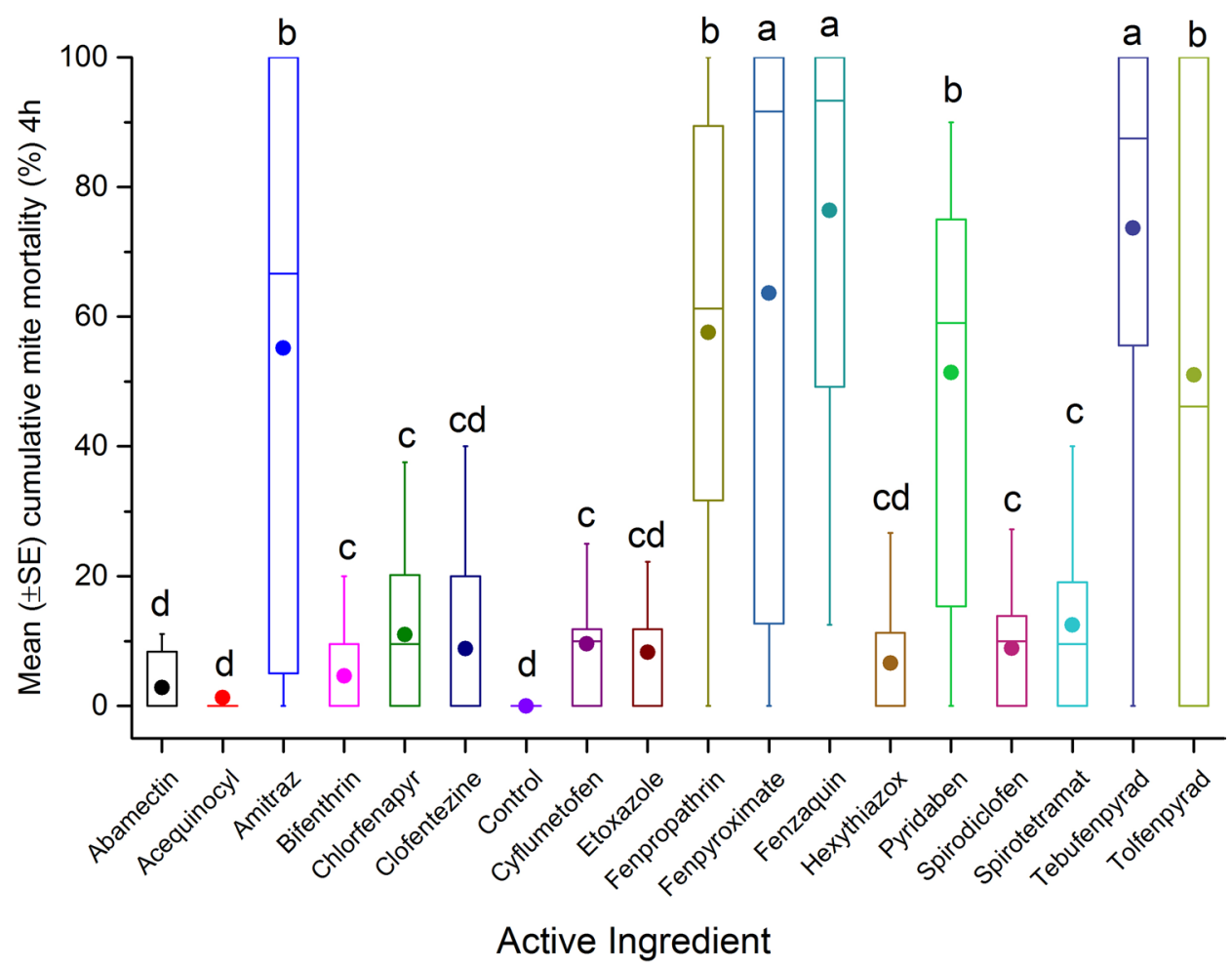

Figure 1. Mean $( \pm \mathrm{SE})$ cumulative mite mortality (\%) during $4 \mathrm{~h}$ exposure to different dilutions $\left(0.1 \mathrm{mgL}^{-1}, 1\right.$ $\mathrm{mgL}^{-1}, 10 \mathrm{mgL}^{-1}, 100 \mathrm{mgL}^{-1}, 1,000 \mathrm{mgL}^{-1}$, or $10,000 \mathrm{mgL}^{-1}$ ) of tested AIs in acute surface contact toxicity assay using $20 \mathrm{~mL}$ borosilicate glass scintillation vials. A group of mites was treated with different dilutions of amitraz as reference control, or left untreated (control) as negative control. The boxplots present the standard error (length of box), mean (solid circle), median (horizontal line), 5th and 95th percentiles (lower and upper vertical lines). Each box indicates average mortality for replications of each AI $(n=24)$ or control $(n=4)$. Means with the same letter among treatments are not significantly different $(p>0.05)$.

treatment periods. Mitaban $(74.1 \pm 7 \%)$ and Capture $(64.4 \pm 6.4 \%)$ had the greatest cumulative mite mortality, compared to other FPs after $4 \mathrm{~h}$ exposure (Fig. 3). The highest mortalities were recorded on mites exposed to Mitaban $(100 \pm 3.1 \%)$, Capture $(98.5 \pm 2.8 \%)$, Pylon $(92.5 \pm 2.8 \%)$, Apollo $(90.1 \pm 3.1 \%)$ and Fujimite $(89 \pm 2.8 \%)$ after 24 h (Fig. 4).

AIs topical toxicity assay. Topical application of the AIs $(\mathrm{n}=17)$ via micro-applicator indicated a higher and non-significant cumulative mite mortality occurred with treatments of: chlorfenapyr $(97.1 \pm 4.8 \%)$, bifenthrin $(95 \pm 4.8 \%)$, fenpyroximate $(93 \pm 3.4 \%)$, tebufenpyrad $(92.2 \pm 4.8 \%)$, and tolfenpyrad $(83.8 \pm 4.8 \%)$ when compared to amitraz $(84.2 \pm 4.8 \%)$. Other AIs presented a significantly lower $(\leq 75 \%)$ mite mortality rate in comparison to reference control, amitraz $(\mathrm{F}=39.88 ; \mathrm{df}=17,417 ; \mathrm{p}<0.0001)$ (Fig. 5).

Toxicity assay on honey bees. AIs surface contact toxicity assay. Cumulative bee mortality was significantly different among AIs $(\mathrm{n}=17)$ when a group of newly-emerged worker bees were exposed to the contaminated surface of a $60 \mathrm{~mL}$ Mason jar for a $24 \mathrm{~h}$ period $(\mathrm{F}=13.3 ; \mathrm{df}=17,410 ; \mathrm{p}<0.0001)$. Results indicated that fenazaquin, hexythiazox, etoxazole, clofentezine and cyflumetofen were safe on bees and had a similar or lower bee mortality $(\leq 28 \%)$ compared to amitraz $(39 \%)$. The other AIs had a high rate of bee mortality $(>40 \%)$ in treatment groups (Table 1).

FPs surface contact toxicity assay. Among FPs $(\mathrm{n}=10)$, Avid and Mitaban had the highest $24 \mathrm{~h}$ cumulative bee mortality $(\geq 89 \%)$, which was significantly different from all other FPs. Kanemite, Apollo, Nealta and the negative control (no treatment) showed similar bee mortality $(\leq 11 \%)$ which indicates those treatment groups were safer for bees compared to other FPs $(\mathrm{F}=33.63 ; \mathrm{df}=10,233 ; \mathrm{p}<0.0001)$ (Table 1).

AIs topical toxicity assay. For AIs $(\mathrm{n}=17)$ topically treated in the micro-applicator assay, more than $31 \%$ of bees were killed during a 24 h-period when treated with bifenthrin, abamectin, tolfenpyrad, fenpropathrin, chlorfenapyr, tebufenpyrad, and pyridaben $(\mathrm{F}=19.35 ; \mathrm{df}=17,538 ; \mathrm{p}<0.0001)$. The rest of the AIs had lower and similar cumulative bee mortality ( $\leq 19 \%$ ) compared to amitraz after $24 \mathrm{~h}$ using topical application (Table 1 ). 


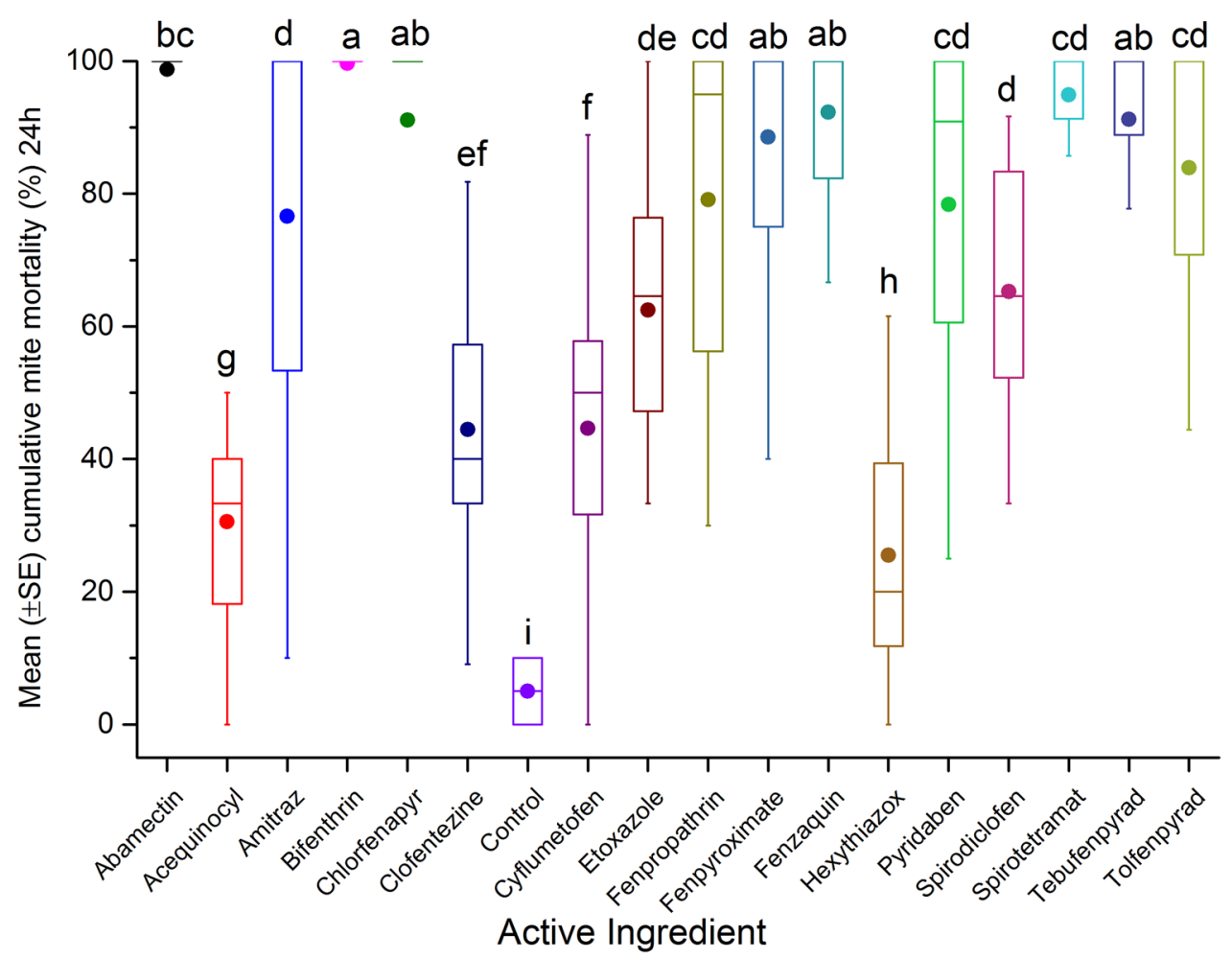

Figure 2. Mean $( \pm \mathrm{SE})$ cumulative mite mortality (\%) during $24 \mathrm{~h}$ exposure to different dilutions $\left(0.1 \mathrm{mgL}^{-1}, 1\right.$ $\mathrm{mgL}^{-1}, 10 \mathrm{mgL}^{-1}, 100 \mathrm{mgL}^{-1}, 1000 \mathrm{mgL}^{-1}$, or $10,000 \mathrm{mgL}^{-1}$ ) of tested AIs in acute surface contact toxicity assay using $20 \mathrm{~mL}$ borosilicate glass scintillation vials. A group of mites was treated with different dilutions of amitraz as reference control, or left untreated (control) as negative control. The boxplots present the standard error (length of box), mean (solid circle), median (horizontal line), 5th and 95th percentiles (lower and upper vertical lines). Each box indicates average mortality for replications of each AI $(n=24)$ or control $(n=4)$. Means with the same letter among treatments are not significantly different $(p>0.05)$.

FPs topical toxicity assay. Honey bees topically treated with FPs $(\mathrm{n}=10)$ led to variable mortality during the 24 h post treatment $(\mathrm{F}=12.08 ; \mathrm{df}=10,348 ; \mathrm{p}<0.0001)$. Avid, Nealta and Capture caused significantly higher cumulative bee mortality $(\geq 37 \%)$ compared to other FPs. However, Pylon, Envidor, Fujimite, Kontos, Apollo, Mitaban and Kanemite had a significantly lower cumulative bee mortality $(\leq 15 \%)$ and was similar to the control (Table 1).

Toxicity and selectivity ratios. The mite and bee lethal toxicity values were calculated based on the corrected rates of mortality after $24 \mathrm{~h}$ using Abbott's formula ${ }^{29}$. The greatest toxicity $\left(\right.$ lower $\mathrm{LC}_{50}$ ) of the AIs to Varroa mites after $24 \mathrm{~h}$ was observed for etoxazole, spirodiclofen, abamectin, acequinocyl, spirotetramat, clofentezine, pyridaben, hexythiazox, chlorfenapyr and fenpropathrin, when compared to the reference control, amitraz. On the other hand, honey bees had a very low toxicity (higher $\mathrm{LC}_{50}$ ) to only etoxazole when compared to amitraz (Table 2). Comparison of $\mathrm{LD}_{50}$ indicated that spirodiclofen and cyflumetofen were both less toxic to $V$. destructor compared to amitraz. Meanwhile, all AIs had similar $\mathrm{LD}_{50}$ values for honey bees, compared to the reference control, amitraz (Table 2).

Based on the bioassay experiments, etoxazole, clofentezine, pyridaben, hexythiazox, chlorfenapyr, fenpropathrin, spirodiclofen and spirotetramat had a high selectively ratio $(>1)$, meaning a lower toxicity to bees than to mites. Meanwhile, abamectin, etoxazole, spirodiclofen, spirotetramat, clofentezine, pyridaben, hexythiazox, chlorfenapyr, fenpropathrin, acequinocyl and tebufenpyrad had a higher toxicity ratio $(<1)$, indicating that these AIs were more toxic to mites than the reference control, amitraz (Table 2). Among FPs evaluated in this study, Nealta and Envidor had a lower mite $\mathrm{LC}_{50}$, similar to Mitaban. In the surface contact test, Avid killed bees in all evaluated dilutions; however, Nealta was less hazardous to bees and had higher $\mathrm{LC}_{50}$ values than the reference control, Mitaban. The results of topical application indicated lower bee $\mathrm{LD}_{50}$ values for Kontos, Capture and Avid compared to Mitaban (Table 3).

Overall, laboratory bioassay results demonstrated potential Varroacide activity for etoxazole, fenazaquin, fenpyroximate, spirodiclofen and spirotetramat all having modes of action different from amitraz (formamidine), and with low adverse affects on bees. However, among these compounds, etoxazole and fenazaquin were the most promising candidates for a new Varroacide. 


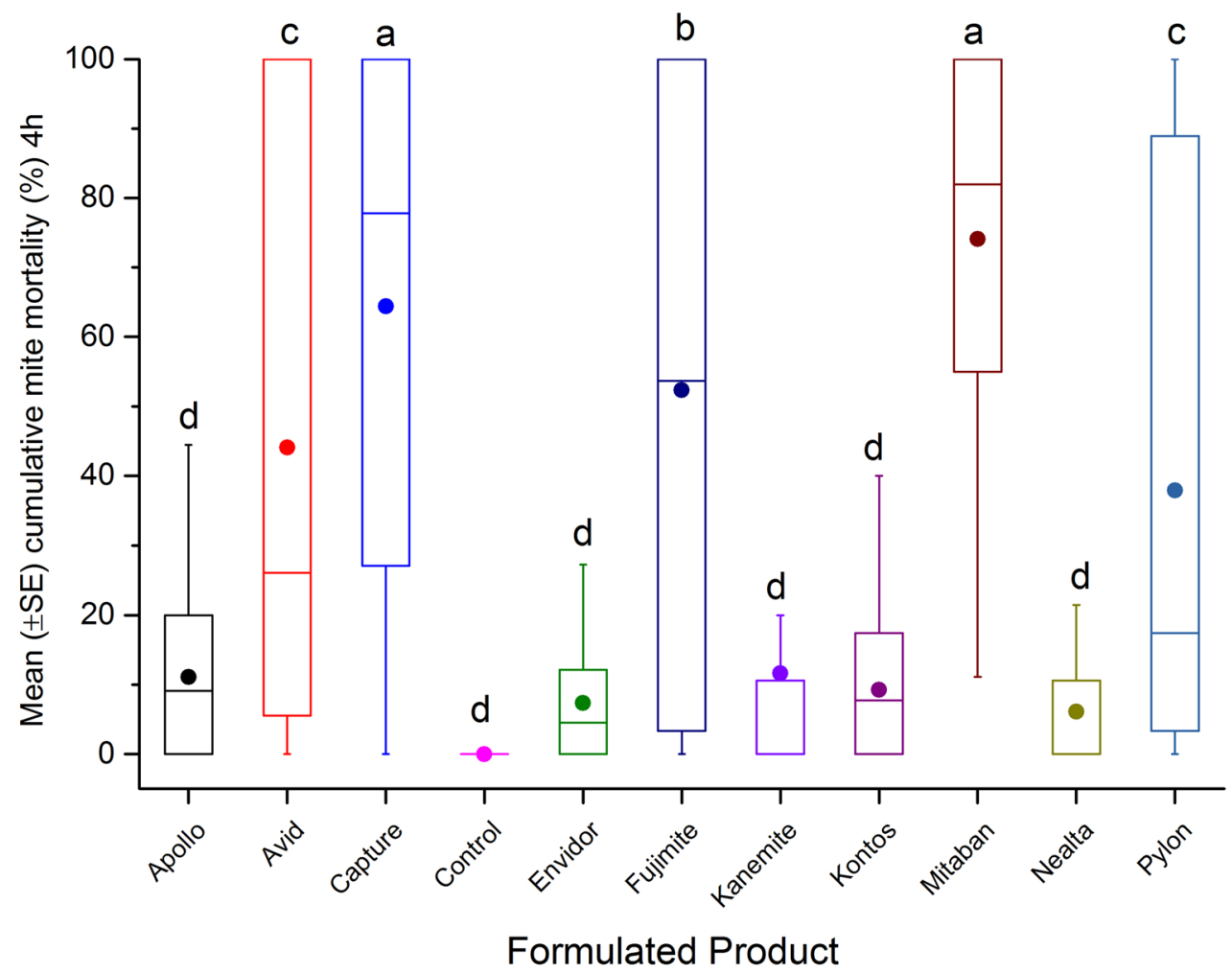

Figure 3. Mean ( \pm SE) cumulative mite mortality (\%) during 4 h exposure to different dilutions $\left(0.1 \mathrm{mgL}^{-1}, 1\right.$ $\mathrm{mgL}^{-1}, 10 \mathrm{mgL}^{-1}, 100 \mathrm{mgL}^{-1}, 1000 \mathrm{mgL}^{-1}$, or $10,000 \mathrm{mgL}^{-1}$ ) of tested FPs in acute surface contact toxicity assay using $20 \mathrm{~mL}$ borosilicate glass scintillation vials. A group of mites was treated with different dilutions of Mitaban as reference control, or left untreated (control) as negative control. The boxplots present the standard error (length of box), mean (solid circle), median (horizontal line), 5th and 95th percentiles (lower and upper vertical lines). Each box indicates average mortality for replications of each FP $(n=24)$ or control $(n=4)$. Means with the same letter among treatments are not significantly different $(p>0.05)$.

\section{Discussion}

Few laboratory or field toxicity investigations have targeted testing the efficacy and safety of commercial miticides on $V$. destructor and A. mellifera ${ }^{24-26}$. Many of the miticides evaluated in this study (e.g. abamectin, chlorfenapyr, cyflumetofen, etoxazole, fenpropathrin, fenazaquin, hexythiazox, pyridaben, spirodiclofen, spirotetramat, and tolfenpyrad) were evaluated globally for the first time on honey bees and Varroa mites. Results suggest that among the 16 AIs evaluated in the laboratory trials etoxazole, fenazaquin, fenpyroximate, spirodiclofen and spirotetramat with different modes of action to those currently registered as Varroacides, show the potential to control Varroa mite. Among the AIs, etoxazole and fenazaquin had the highest mite control efficacy with minimal effects on honey bees. These AIs should be subjected to further testing at the honey bee colony level to determine the effective dose, optimal application method and their effects on colony performance and A. mellifera fitness.

Beekeepers use a variety of miticides to control Varroa mite populations including Apivar (amitraz). Apivar has been used in Canada for more than a decade and remains an effective option for beekeepers. This product has been registered in the USA since 2013, and recently Rinkevich ${ }^{12}$ reported resistance of Varroa mites to amitraz in Louisiana, New York, and South Dakota beekeeping operations. However, in this study, amitraz efficacy was $>90 \%$ at dilution of $>10 \mathrm{mgL}^{-1}$ indicating that amitraz remains an effective product for the control of $V$. destructor in the tested mite population. Despite the wide use of amitraz as a Varroacide, globally, few studies examined the toxicity of amitraz on mites and bees. Santiago et al. ${ }^{30}$, for instance, evaluated the lethal toxicity values of amitraz for Varroa mite as $\mathrm{LC}_{50}=0.23 \mathrm{mgL}^{-1}$ and $\mathrm{LD}_{50}=0.0000017 \mu \mathrm{g} / \mathrm{mite}$; and for honey bee as $\mathrm{LC}_{50}=1.64$ $\mathrm{mgL}^{-1}$ and $\mathrm{LD}_{50}=2.55 \mu \mathrm{g} /$ bee. According Abed et al. ${ }^{31}$, amitraz $\mathrm{LD}_{50}$ was $0.00000216 \mu \mathrm{g} / \mathrm{mite}$ for Varroa mites. Maggi et al. ${ }^{28}$ exposed Varroa mites to amitraz in Petri dishes and reported a high toxicity $\left(\mathrm{LC}_{50}=0.1 \mu \mathrm{g} / \mathrm{dish}\right)$ to mites. However, Elzen et al..$^{32}$ found a higher amitraz $\mathrm{LC}_{50}$ value $(16.35 \mu \mathrm{g} / \mathrm{vial})$ for mites in a glass vial assay. Our studies determined the amitraz $\mathrm{LD}_{50}$ and $\mathrm{LC}_{50}$ values in the tested mite population to be $0.0000132 \mu \mathrm{g} / \mathrm{mite}$ and $17.34 \mathrm{mgL}^{-1}$, when using the glass vial and micro-applicator methods, respectively. The difference between studies could be due to any of the following: variabilities in mite populations, history of exposure to amitraz, duration of bioassay, methods and statistical analyses.

The surface contact application (glass vial assay) showed a rapid and simple method to screen new compounds having Varroacidal properties. Consistent with other studies ${ }^{20,22,23}$, this method can also be adopted for assessment of Varroa mite populations resistance to miticides. Frequent monitoring for Varroa resistance to synthetic 


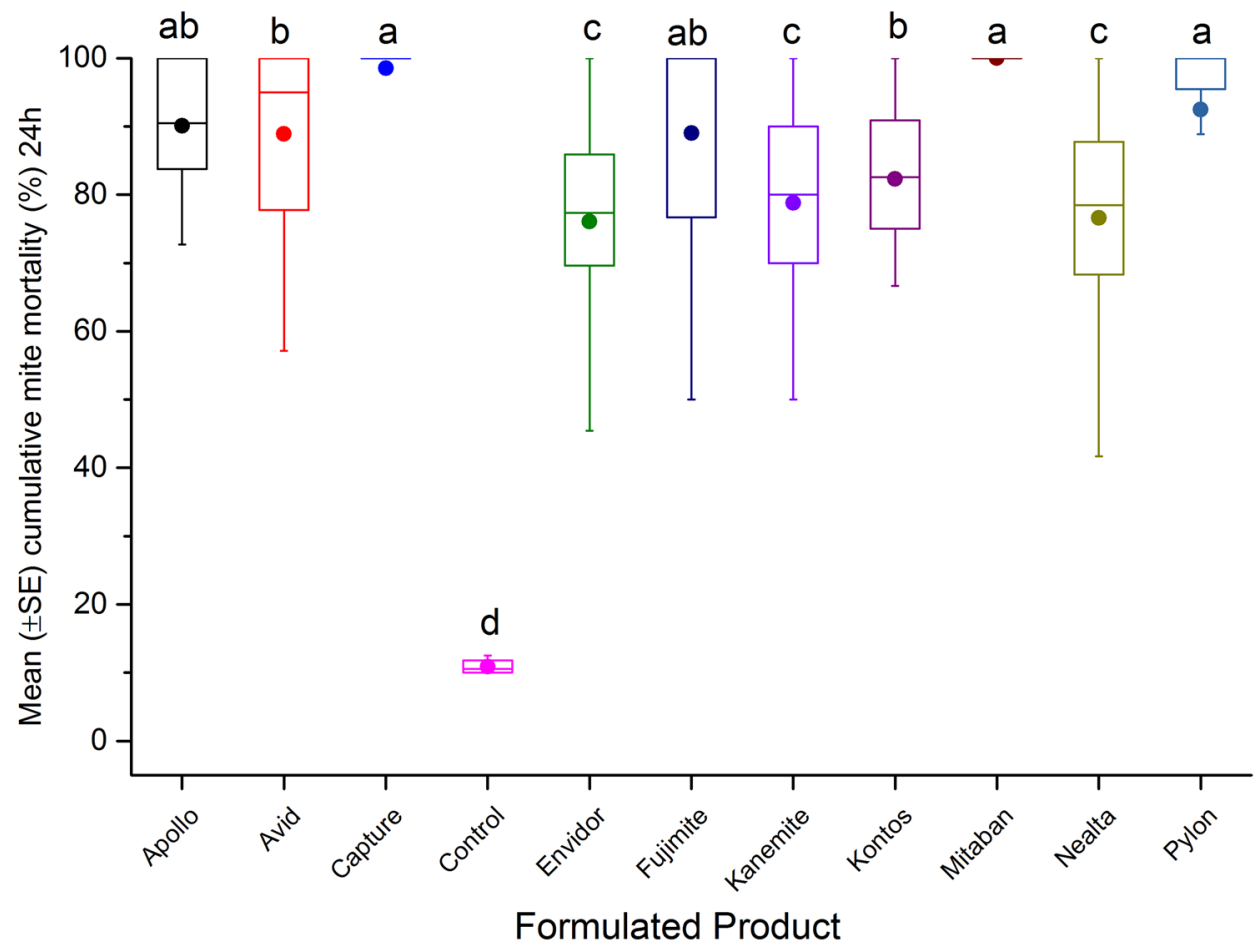

Figure 4. Mean $( \pm \mathrm{SE})$ cumulative mite mortality $(\%)$ during $24 \mathrm{~h}$ exposure to different dilutions $\left(0.1 \mathrm{mgL}^{-1}, 1\right.$ $\mathrm{mgL}^{-1}, 10 \mathrm{mgL}^{-1}, 100 \mathrm{mgL}^{-1}, 1000 \mathrm{mgL}^{-1}$, or $10,000 \mathrm{mgL}^{-1}$ ) of tested FPs in acute surface contact toxicity assay using $20 \mathrm{~mL}$ borosilicate glass scintillation vials. A group of mites was treated with different dilutions of Mitaban as reference control, or left untreated (control) as negative control. The boxplots present the standard error (length of box), mean (solid circle), median (horizontal line), 5th and 95th percentiles (lower and upper vertical lines). Each box indicates average mortality for replications of each FP $(n=24)$ or control $(n=4)$. Means with the same letter among treatments are not significantly different $(p>0.05)$.

Varroacides are important for honey bee colony health and the long-term sustainability of the beekeeping industry in Canada. In the past, mite resistance was evaluated using a variety of methods, with mite susceptibility to chemicals varying depending on the region. Kamler et al. ${ }^{21}$ developed a polypropylene vial (instead of glass vial) bioassay and documented a higher toxicity for amitraz in the resistant $\left(\mathrm{LC}_{50}=0.00802 \mathrm{mgL}^{-1}\right)$ compared to the susceptible $\left(\mathrm{LC}_{50}=0.25104 \mathrm{mgL}^{-1}\right)$ mite populations during a $24 \mathrm{~h}$-period. The studies ${ }^{30,33}$ conducted in Mexico on susceptible mites estimated $\mathrm{LC}_{50}$ for amitraz to be $0.23-0.526 \mathrm{mgL}^{-1}$ using the Petri dish, topical and spraying methods. In our study, mites were collected from high-Varroa infested colonies with no reported resistance to amitraz. The bioassay established an $\mathrm{LC}_{50}$ reference point for amitraz of $17.34 \mathrm{mgL}^{-1}$, for susceptible Varroa mite populations tested in this study.

Other research has focused on exposing honey bee workers to pesticides using feeding ${ }^{34}$, surface contact in the Petri dishes ${ }^{35}$ and topical ${ }^{36,37}$ methods. In this study, newly-emerged worker bees were exposed to chemicals by coating the inside of $60 \mathrm{~mL}$ glass Mason jar. When specifically looking at amitraz and the formulated product Mitaban, the bioassay confirmed a significantly higher bee mortality when bees were exposed to higher dilutions of both compounds. For example, when the inner surface of jars $\left(67.75 \mathrm{~cm}^{-2}\right)$ were coated with $1000 \mathrm{mgL}^{-1}$ amitraz, bees were exposed to $0.0074 \mathrm{mgcm}^{-2}$ (approximately $0.074 \mathrm{mg} / \mathrm{bee}$ ) of amitraz, which caused $100 \%$ mortality. This result is not surprising because when Varroa-infested colonies are treated with Apivar, bees are exposed $5 \mathrm{mgcm}^{-2}$ (approximately $0.00042 \mathrm{mg} / \mathrm{bee}$ ) of the AI (amitraz) over a 6-8 week treatment period. To explain high bee mortality in the Mason jar experiment, bees were exposed to a larger quantity of amitraz for a shorter period of time and in a confined space, unlike a colony environment.

Other evaluated AIs in the surface contact method had different adverse effects on bees when compared to amitraz. Johnson et al. ${ }^{37}$ reported bees having a higher toxicity to amitraz compared to bees exposed to fenpyroximate, tau-fluvalinate, coumaphos and thymol. The tolerance of bees towards some miticides such as tau-fluvalinate, coumaphos and fenpyroximate appear to be associated to P450s detoxification activities ${ }^{37}$. For honey bees, the mode of action of amitraz is unknown. Dahlgren et al. $^{25}$ determined that for amitraz, honey bee $\mathrm{LD}_{50}$ value was $0.00267 \%$, when using the topical application $(1 \mu \mathrm{L} / \mathrm{bee})$ on the thorax, with this value being higher than the our study where the value was determines to be $0.00084 \%(=0.00045 \mu \mathrm{g} / \mathrm{bee})$. They also found that amitraz $\left(\mathrm{LD}_{50}=21.8 \mu \mathrm{gg}^{-1}\right)$ was more toxic to queens than fenpyroximate $\left(\mathrm{LD}_{50}>1620 \mu \mathrm{gg}^{-1}\right)^{25}$. Queens, on the other hand, had a higher tolerance to amitraz and fenpyroximate than workers did. Amitraz was also toxic to bees when treated orally $\left(\mathrm{LD}_{50}=7.082 \mu \mathrm{L} /\right.$ bee $)$ for $24 \mathrm{~h}^{38}$, with higher mortality rate $(>60 \%)$ at dilutions greater than $1000 \mathrm{mgL}^{-138,39}$. In our study, oral toxicity was not evaluated, but cumulative bee mortality was less than $41 \%$ when bees were in contact with amitraz at $\leq 100 \mathrm{mgL}^{-1}$ in the glass Mason jars. 


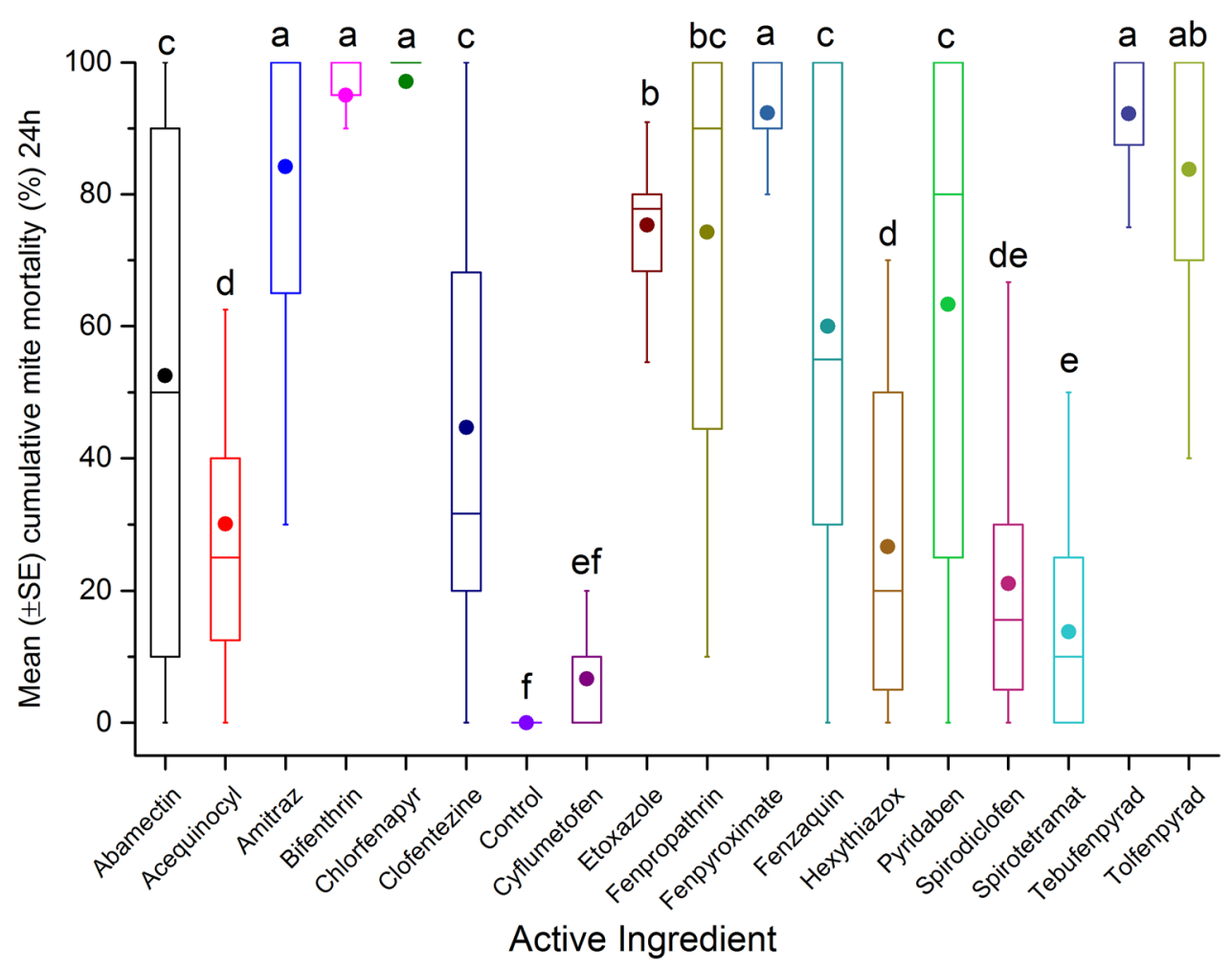

Figure 5. Mean $( \pm \mathrm{SE})$ cumulative mite mortality (\%) during $24 \mathrm{~h}$ exposure to different dilutions $(0.0000117 \mu \mathrm{g} / \mathrm{mite}, 0.000117 \mu \mathrm{g} / \mathrm{mite}, 0.00117 \mu \mathrm{g} / \mathrm{mite}, 0.0117 \mu \mathrm{g} / \mathrm{mite}, 0.117 \mu \mathrm{g} / \mathrm{mite}$ or $1.17 \mu \mathrm{g} / \mathrm{mite})$ of tested AIs in topical toxicity assay. Each Varroa mite was topically treated with $0.15 \mu \mathrm{L}$ of each AI using microapplicator. A group of mites was treated with different dilutions of amitraz as reference control, or left untreated (control) as negative control. The boxplots present the standard error (length of box), mean (solid circle), median (horizontal line), 5th and 95th percentiles (lower and upper vertical lines). Each box indicates average mortality for replications of each AI $(n=24)$ or control $(n=4)$. Means with the same letter among treatments are not significantly different $(p>0.05)$.

Yashima discovered etoxazole from the oxazoline chemical class in the $1980 \mathrm{~s}^{40}$. This AI was commercialized in $1998^{41}$ for the control of immature mites, aphids, moths and other phytophagous insects in crop. Our trials were the first to investigate the effect of etoxazole on $V$. destructor and A. mellifera. It was found that etoxazole had a higher toxicity $\left(\mathrm{LC}_{50}=0.0000121 \mathrm{mgL}^{-1}\right)$ to mites compared to amitraz and was safe for use on honey bee. The vial test supported the result, with an acceptable efficacy $(70 \%)$ of mite control when using etoxazole, compared to amitraz (77\%). Meanwhile, the mortality rate was $<9 \%$ when bees were exposed to $0.1-10,000 \mathrm{mgL}^{-1}$ of etoxazole in Mason jars. Overall, etoxazole was effective in the bioassay tests under laboratory conditions, and it is recommended that future evaluation take place under field conditions.

Fenazaquin from the chemical class quinazoline was introduced in 1988 by Dow AgroSciences ${ }^{42}$. Quinazoline products were reported to have minimal impact on many beneficial insects and mites ${ }^{43}$. On target species, fenazaquin is known to inhibit the mitochondrial electron transport chain and has been used against spider mites. For the Asian honey bee, Apis cerana F., a 60\% mortality was observed thirty minutes after sunflower leaves were treated with fenazaquin, but toxicity dropped to $9.6 \%$ when exposure occurred one day after treatment. The toxicity $\left(\mathrm{LD}_{50}\right)$ of fenazaquin to A. cerana was $1.5-508 \mu \mathrm{g} / \mathrm{bee}^{44}$. Our study is the first to evaluate the effects of fenazaquin on $A$. mellifera and $V$. destructor. The surface contact toxicity results revealed that fenazaquin had the potential to kill $76 \%$ and $92 \%$ of Varroa mites, after a $4 \mathrm{~h}$ exposure and $24 \mathrm{~h}$ post-treatment, respectively. Fenazaquin had no negative effects on bees at lower dilutions $\left(<100 \mathrm{mgL}^{-1}\right)$ which also resulted in low rates of bee mortality $(0-12 \%)$ similar to that of amitraz. Fenazaquin toxicity $\left(\mathrm{LC}_{50}=33.62 \mathrm{mgL}^{-1}\right)$ on mites was similar to amitraz. Laboratory bioassays indicated that fenazaquin was less harmful to bees compared to Mitaban, but only in the surface contact test. On the other hand, fenazaquin along with tebufenpyrad and fenpyroximate resulted in rapid mite kill in a short period after $4 \mathrm{~h}$ exposure in the glass vial test. The results suggest that fenazaquin could be further evaluated under field conditions as a potential Varroacide.

This study also evaluated a group of miticides belonging to the pyrazole class of chemical (Supplementary Table S1). These chemicals target mitochondrial complex I, with low to moderate effects on beneficial insects and predator mites. Miticides examined in this study were: tebufenpyrad, tolfenpyrad and fenpyroximate. Our results revealed that tebufenpyrad may be an effective miticide to control $V$. destructor, due to a high cumulative mite mortality (73\%), which was similar to fenazaquin (76\%) and fenpyroximate (63\%), but significantly higher than amitraz (55\%), when tested $4 \mathrm{~h}$ exposure in surface contact test. Ali et al. ${ }^{24}$ exposed honey bee colonies to tebufenpyrad and found that Varroa mite abundance dropped by $77 \%$. At the same time, the use of tebufenpyrad 


\begin{tabular}{|c|c|c|}
\hline & Surface contact toxicity assay & Topical toxicity assay \\
\hline \multicolumn{3}{|l|}{ AIs } \\
\hline Abamectin & $75.6 \pm 7.3^{\mathrm{a}}$ & $67.1 \pm 4.9^{\mathrm{ab}}$ \\
\hline Acequinocyl & $40.8 \pm 7.3^{c}$ & $10.3 \pm 4.9^{\mathrm{cd}}$ \\
\hline Amitraz & $39 \pm 7.3^{\mathrm{e}}$ & $19 \pm 4.9^{\mathrm{cd}}$ \\
\hline Bifenthrin & $73.2 \pm 7.3^{\mathrm{a}}$ & $72.3 \pm 5^{\mathrm{a}}$ \\
\hline Chlorfenapyr & $51.3 \pm 7.3^{\mathrm{c}}$ & $40.9 \pm 5^{\mathrm{b}}$ \\
\hline Clofentezine & $4.2 \pm 7.3^{\mathrm{g}}$ & $13.4 \pm 5.6^{\mathrm{cd}}$ \\
\hline Control (for AIs) & $2.5 \pm 1.8^{\mathrm{g}}$ & $1 \pm 2^{\mathrm{e}}$ \\
\hline Cyflumetofen & $0.4 \pm 7.3^{\mathrm{g}}$ & $4.6 \pm 5^{\mathrm{de}}$ \\
\hline Etoxazole & $8.7 \pm 7.3^{\mathrm{fg}}$ & $2.8 \pm 6.4^{\mathrm{de}}$ \\
\hline Fenazaquin & $28.5 \pm 7.3^{\mathrm{ef}}$ & $18.3 \pm 6.4^{\mathrm{cd}}$ \\
\hline Fenpropathrin & $57.8 \pm 7.3^{\mathrm{bc}}$ & $44.2 \pm 6.4^{\mathrm{b}}$ \\
\hline Fenpyroximate & $60.9 \pm 5.2^{\mathrm{bc}}$ & $11.9 \pm 5.5^{\mathrm{cd}}$ \\
\hline Hexythiazox & $21.5 \pm 8^{\mathrm{f}}$ & $1.8 \pm 6.4^{\mathrm{de}}$ \\
\hline Pyridaben & $53.4 \pm 7.3^{\mathrm{bc}}$ & $30.5 \pm 6.4^{\mathrm{b}}$ \\
\hline Spirodiclofen & $69.4 \pm 7.3^{\mathrm{ab}}$ & $8.6 \pm 4.9^{\mathrm{d}}$ \\
\hline Spirotetramat & $61.4 \pm 7.3^{\mathrm{ab}}$ & $9.6 \pm 4.9^{\mathrm{d}}$ \\
\hline Tebufenpyrad & $81.9 \pm 7.3^{\mathrm{a}}$ & $32.7 \pm 6.4^{\mathrm{b}}$ \\
\hline Tolfenpyrad & $46.6 \pm 7.3^{c}$ & $47.3 \pm 6.4^{\mathrm{b}}$ \\
\hline \multicolumn{3}{|l|}{ FPs } \\
\hline Apollo & $7 \pm 5.4^{\mathrm{e}}$ & $7.7 \pm 4.8^{\mathrm{b}}$ \\
\hline Avid & $98.8 \pm 5.4^{\mathrm{a}}$ & $49.9 \pm 4.5^{\mathrm{a}}$ \\
\hline Capture & $77.5 \pm 5.4^{\mathrm{b}}$ & $54 \pm 4.8^{\mathrm{a}}$ \\
\hline Control (for FPs) & $2.5 \pm 1.3^{\mathrm{e}}$ & $1 \pm 1.8^{\mathrm{b}}$ \\
\hline Envidor & $71.6 \pm 5.4^{\mathrm{b}}$ & $13.4 \pm 4.9^{\mathrm{b}}$ \\
\hline Fujimite & $32.6 \pm 5.4^{\mathrm{d}}$ & $13.3 \pm 4.5^{\mathrm{b}}$ \\
\hline Kanemite & $10.9 \pm 5.4^{\mathrm{de}}$ & $7 \pm 4.8^{\mathrm{b}}$ \\
\hline Kontos & $32.1 \pm 5.4^{\mathrm{d}}$ & $11.8 \pm 4.8^{\mathrm{b}}$ \\
\hline Mitaban & $89.5 \pm 5.4^{\mathrm{ab}}$ & $6.3 \pm 4.9^{\mathrm{b}}$ \\
\hline Nealta & $2.1 \pm 5.4^{\mathrm{e}}$ & $37.1 \pm 4.8^{\mathrm{ab}}$ \\
\hline Pylon & $55.1 \pm 5.4^{c}$ & $15.2 \pm 4.8^{\mathrm{b}}$ \\
\hline
\end{tabular}

Table 1. Mean ( \pm SE) cumulative bee mortality (\%) during 24 h exposure to different dilutions of AIs $(n=17)$ or FPs $(n=10)$ in acute surface contact (Mason jar) or topical (micro-applicator) toxicity assays. Amitraz and Mitaban were tested as reference control for AIs and FPs, respectively. Means with the same letter in each column among AIs or FPs treatments are not significantly different $(p>0.05)$.

resulted in a reduced brood area, adult population, and an increase incidence of queen failure. With findings consistent with Ali et al. ${ }^{24}$, we found unacceptable bee mortality in jars (82\%) and in topical (33\%) treatment methods. Despite finding high rates of bee mortality, further study may identify an effective dose for control of mites, while remaining safe for use on honey bees.

In the pyrazole group, fenpyroximate was commercialized in 1991 by Nihon Noyaku ${ }^{45}$ and introduced as Hivastan in the USA in 2007 for the control $V$. destructor ${ }^{46}$. This product was not registered for use as a Varroacide in Canada. Hivastan was formulated and applied to colonies in a patty containing $0.3 \%$ of the AI. To date, there is minimal evidence for its efficacy at controlling Varroa mites, or its adverse effects on bees. Hivastan was only used in the USA (2008-2010) ${ }^{46}$, and due to high bee kill following an application of the registered formulation, the registrant pulled the registration with the Environmental Protection Agency (EPA). Further investigations have reported that fenpyroximate affects $A$. mellifer ${ }^{25,47}$. For example, fenpyroximate increased aggression by $31 \%$ in treated bees ${ }^{47}$ and caused fewer recapturing of drones two weeks post-treatment ${ }^{37}$. Our result showed a lower level of toxicity $\left(\mathrm{LD}_{50}=0.023 \%\right)$ for fenpyroximate compared to a previous report $(0.003 \%)^{25}$. Furthermore, our results also showed that newly-emerged worker bees tolerated fenpyroximate at lower doses, while cumulative mite mortality was $>60 \%$, when exposed to $<10 \mathrm{mgL}^{-1}$ of AI. It was also observed that significantly higher rates of cumulative mite mortality for fenpyroximate occurred during the $4 \mathrm{~h}(63 \%)$ or $24 \mathrm{~h}$ (92\%) compared to the reference control (55\% and 76\%, respectively). Currently, no evidence is available documenting Varroa mite resistance to fenpyroximate. However, Kim et al. ${ }^{48}$ identified fenpyroximate resistance in two-spotted spider mite (T. urticae). Although Hivastan is no longer available as a tool for controlling Varroa mites, it is recommended that this product be re-investigated to determine an effective dose against mites, at a level safe for bees under field conditions. 


\begin{tabular}{|c|c|c|c|c|c|c|}
\hline AIs & Mite $\mathrm{LC}_{50}\left(\mathrm{mgL}^{-1}\right)$ & Mite $\mathrm{LD}_{50}(\mu \mathrm{g} / \mathrm{mite})$ & Bee $\mathrm{LC}_{50}\left(\mathrm{mgL}^{-1}\right)$ & Bee $\mathrm{LD}_{50}(\mu \mathrm{g} / \mathrm{bee})$ & Toxicity ratio $^{a}$ & Selectivity ratio $^{\mathrm{b}}$ \\
\hline Abamectin & $1.68 \mathrm{E}-03^{\mathrm{C}}$ & $9.65 \mathrm{E}-07^{\mathrm{C}}$ & $2.79 \mathrm{E}-01^{\mathrm{BCDE}}$ & $3.74 \mathrm{E}-05^{\mathrm{CD}}$ & 9.69E-05 & $1.66 \mathrm{E}+02$ \\
\hline Acequinocyl & $1.18 \mathrm{E}-01^{\mathrm{C}}$ & $3.39 \mathrm{E}-06^{\mathrm{BC}}$ & $4.11 \mathrm{E}-02^{\mathrm{BCDE}}$ & $2.07 \mathrm{E}-02^{\mathrm{ABC}}$ & $6.83 \mathrm{E}-03$ & $3.47 \mathrm{E}-01$ \\
\hline Amitraz & $1.73 \mathrm{E}+01^{\mathrm{B}}$ & $1.32 \mathrm{E}-05^{\mathrm{C}}$ & $7.02^{\mathrm{BCDE}}$ & $1.18 \mathrm{E}-03^{\mathrm{ABCD}}$ & 1 & $4.05 \mathrm{E}-01$ \\
\hline Bifenthrin & $2.44 \mathrm{E}+08^{\mathrm{A}}$ & $2.29 \mathrm{E}-07^{\mathrm{C}}$ & $7.64 \mathrm{E}-04^{\mathrm{BCDE}}$ & $2.99 \mathrm{E}-06^{\mathrm{CD}}$ & $1.41 \mathrm{E}+07$ & $3.13 \mathrm{E}-12$ \\
\hline Chlorfenapyr & $4.07 \mathrm{E}-02^{\mathrm{C}}$ & $7.79 \mathrm{E}-06^{\mathrm{C}}$ & $2.78 \mathrm{E}-01^{\mathrm{BCDE}}$ & $6.95 \mathrm{E}-05^{\mathrm{CD}}$ & $2.34 \mathrm{E}-03$ & 6.84 \\
\hline Clofentezine & $6.69 \mathrm{E}-03^{\mathrm{C}}$ & $3.48 \mathrm{E}-07^{\mathrm{C}}$ & $1.81 \mathrm{E}+02^{\mathrm{C}}$ & $3.39 \mathrm{E}-02^{\mathrm{AB}}$ & $3.86 \mathrm{E}-04$ & $2.7 \mathrm{E}+04$ \\
\hline Cyflumetofen & $4.31 \mathrm{E}+06^{\mathrm{A}}$ & $1.89 \mathrm{E}-03^{\mathrm{AB}}$ & $1.08 \mathrm{E}+02^{\mathrm{BC}}$ & $7.15 \mathrm{E}-04^{\mathrm{CD}}$ & $2.49 \mathrm{E}+05$ & $2.5 \mathrm{E}-05$ \\
\hline Etoxazole & $1.21 \mathrm{E}-05^{\mathrm{C}}$ & $7.91 \mathrm{E}-10^{\mathrm{C}}$ & $1.38 \mathrm{E}+03^{\mathrm{A}}$ & $8.92 \mathrm{E}-02^{\mathrm{AB}}$ & $6.98 \mathrm{E}-07$ & $1.14 \mathrm{E}+08$ \\
\hline Fenazaquin & $3.36 \mathrm{E}+01^{\mathrm{B}}$ & $2.21 \mathrm{E}-06^{\mathrm{C}}$ & $1.93 \mathrm{E}+01^{\mathrm{BCDE}}$ & $1.02 \mathrm{E}-03^{\mathrm{CD}}$ & 1.94 & $5.75 \mathrm{E}-01$ \\
\hline Fenpropathrin & $8.64 \mathrm{E}-02^{\mathrm{C}}$ & $9.3 \mathrm{E}-06^{\mathrm{C}}$ & $5.5 \mathrm{E}-01^{\mathrm{BCDE}}$ & $3.21 \mathrm{E}-03^{\mathrm{ABCD}}$ & $4.98 \mathrm{E}-03$ & 6.37 \\
\hline Fenpyroximate & $3.23 \mathrm{E}+01^{\mathrm{B}}$ & $2.98 \mathrm{E}-06^{\mathrm{C}}$ & $4.32 \mathrm{E}-01^{\mathrm{BCDE}}$ & $1.82 \mathrm{E}-01^{\mathrm{A}}$ & 1.86 & $1.34 \mathrm{E}-02$ \\
\hline Hexythiazox & $3.46 \mathrm{E}-02^{\mathrm{C}}$ & $1.01 \mathrm{E}-04^{\mathrm{BC}}$ & $3.45 \mathrm{E}-01^{\mathrm{BCDE}}$ & $1.01 \mathrm{E}-02^{\mathrm{ABC}}$ & $1.99 \mathrm{E}-03$ & 9.98 \\
\hline Pyridaben & $2.13 \mathrm{E}-02^{\mathrm{C}}$ & $1.13 \mathrm{E}-05^{\mathrm{C}}$ & $2.94^{\mathrm{BCDE}}$ & $3.79 \mathrm{E}-02^{\mathrm{AB}}$ & $1.23 \mathrm{E}-03$ & $1.38 \mathrm{E}+02$ \\
\hline Spirodiclofen & $2.73 \mathrm{E}-04^{\mathrm{C}}$ & $6.49 \mathrm{E}-01^{\mathrm{A}}$ & $9.28 \mathrm{E}-04^{\mathrm{BCDE}}$ & $6.27 \mathrm{E}-03^{\mathrm{ABC}}$ & $1.58 \mathrm{E}-05$ & 3.39 \\
\hline Spirotetramat & $3.16 \mathrm{E}-03^{\mathrm{C}}$ & $4.1 \mathrm{E}-06^{\mathrm{BC}}$ & $5.78 \mathrm{E}-03^{\mathrm{BCDE}}$ & $5.92 \mathrm{E}-02^{\mathrm{AB}}$ & $1.82 \mathrm{E}-04$ & 1.83 \\
\hline Tebufenpyrad & $1.54 \mathrm{E}+01^{\mathrm{BC}}$ & $2 \mathrm{E}-05^{\mathrm{BC}}$ & $2.72 \mathrm{E}-03^{\mathrm{BCDE}}$ & $1.66 \mathrm{E}-06^{\mathrm{CD}}$ & $8.9 \mathrm{E}-01$ & $1.76 \mathrm{E}-04$ \\
\hline Tolfenpyrad & $9.55 \mathrm{E}+01^{\mathrm{B}}$ & $3.23 \mathrm{E}-06^{\mathrm{C}}$ & $5.8^{\mathrm{BCDE}}$ & $1.61 \mathrm{E}-09^{\mathrm{CD}}$ & 5.51 & $6.07 \mathrm{E}-02$ \\
\hline
\end{tabular}

Table 2. Lethal concentration fifty $\left(\mathrm{LC}_{50}\right)$ and dose fifty $\left(\mathrm{LD}_{50}\right)$ values for $24 \mathrm{~h}$ responses of $V$. destructor and A. mellifera to tested AIs $(\mathrm{n}=17)$. Amitraz was evaluated as reference control. Values with overlapping CIs in each column are not considered significantly different as indicated with the same letter $(p>0.05)$. ${ }^{\text {a }}$ Toxicity ratio was calculated by dividing the $\mathrm{LC}_{50}$ for each $\mathrm{AI}$ by $\mathrm{LC}_{50}$ for Amitraz. ${ }^{\mathrm{b}}$ Selectivity ratio was calculated by dividing the $\mathrm{LC}_{50}$ for honey bee by $\mathrm{LC}_{50}$ for Varroa mite.

\begin{tabular}{|c|c|c|c|c|c|}
\hline FPs & Mite $\mathrm{LC}_{50}\left(\mathrm{mgL}^{-1}\right)$ & Bee $\mathrm{LC}_{50}\left(\mathrm{mgL}^{-1}\right)$ & Bee $\mathrm{LD}_{50}(\mu \mathrm{g} / \mathrm{bee})$ & Toxicity ratio $^{\mathrm{a}}$ & Selectivity ratio ${ }^{b}$ \\
\hline Apollo & $1.89 \mathrm{E}-01^{\mathrm{C}}$ & $1.7 \mathrm{E}+02^{\mathrm{A}}$ & $7.85 \mathrm{E}-03^{\mathrm{ABC}}$ & $5.12 \mathrm{E}+01$ & $9 \mathrm{E}+02$ \\
\hline Avid & $3.01 \mathrm{E}+01^{\mathrm{B}}$ & - & $3.68 \mathrm{E}-04^{\mathrm{C}}$ & $8.14 \mathrm{E}+03$ & - \\
\hline Capture & $3.6 \mathrm{E}+02^{\mathrm{B}}$ & $1.3 \mathrm{E}-01^{\mathrm{C}}$ & $2.06 \mathrm{E}-04^{\mathrm{C}}$ & $9.73 \mathrm{E}+04$ & $3.62 \mathrm{E}-04$ \\
\hline Envidor & $1.42 \mathrm{E}-04^{\mathrm{D}}$ & $6.35 \mathrm{E}-03^{\mathrm{C}}$ & $6.57 \mathrm{E}-04^{\mathrm{BC}}$ & $3.84 \mathrm{E}-02$ & $4.47 \mathrm{E}+01$ \\
\hline Fujimite & $9.86 \mathrm{E}+01^{\mathrm{B}}$ & $7.31^{\mathrm{BC}}$ & $3.04 \mathrm{E}-01^{\mathrm{A}}$ & $2.66 \mathrm{E}+04$ & $7.42 \mathrm{E}-02$ \\
\hline Kanemite & $2.42 \mathrm{E}-02^{\mathrm{C}}$ & $3.88^{\mathrm{BC}}$ & $2.19 \mathrm{E}-02^{\mathrm{ABC}}$ & 6.54 & $1.61 \mathrm{E}+02$ \\
\hline Kontos & $9.88 \mathrm{E}+06^{\mathrm{A}}$ & $3.18^{\mathrm{BC}}$ & $1.24 \mathrm{E}-05^{\mathrm{C}}$ & $2.67 \mathrm{E}+09$ & $3.22 \mathrm{E}-07$ \\
\hline Mitaban & $3.7 \mathrm{E}-03^{\mathrm{CD} *}$ & $5.33 \mathrm{E}-02^{\mathrm{C}}$ & $7.1 \mathrm{E}-02^{\mathrm{AB}}$ & 1 & $1.44 \mathrm{E}+01$ \\
\hline Nealta & $3.81 \mathrm{E}-05^{\mathrm{D}}$ & $1.4 \mathrm{E}+02^{\mathrm{B}}$ & $3.82 \mathrm{E}-04^{\mathrm{BC}}$ & $1.03 \mathrm{E}-02$ & $3.68 \mathrm{E}+06$ \\
\hline Pylon & $1.85 \mathrm{E}+03^{\mathrm{B}}$ & $1.01^{\mathrm{C}}$ & $1.58 \mathrm{E}-01^{\mathrm{A}}$ & $5 \mathrm{E}+05$ & $5.47 \mathrm{E}-04$ \\
\hline
\end{tabular}

Table 3. Lethal concentration fifty $\left(\mathrm{LC}_{50}\right)$ and dose fifty $\left(\mathrm{LD}_{50}\right)$ values for $24 \mathrm{~h}$ responses of $V$. destructor and A. mellifera to tested FPs $(\mathrm{n}=10)$. Mitaban was evaluated as reference control. Values with overlapping CIs in each column are not considered significantly different as indicated with the same letter $(p>0.05)$. ${ }^{a}$ Toxicity ratio was calculated by dividing the $\mathrm{LC}_{50}$ for each $\mathrm{AI}$ by $\mathrm{LC}_{50}$ for Mitaban. ${ }^{\mathrm{b}}$ Selectivity ratio was calculated by dividing the $\mathrm{LC}_{50}$ for honey bee by $\mathrm{LC}_{50}$ for Varroa mite. ${ }^{*}$ The mite $\mathrm{LC}_{50}$ value for Mitaban was determined using serial dilutions of $0.0001-100 \mathrm{mgL}^{-1}$.

Tetronic acids are a group of miticides including spirodiclofen and spirotetramat that inhibit lipid biosynthesis. They are used to control a number of phytophagous mites. Spirodiclofen was commercialized by Bayer CropScience in 2002. Only a few studies looked at the influence of tetronic acid on A. mellifera and V. destructor. In a trial, the product Envidor (spirodiclofen) was found to have an $\mathrm{LD}_{50}$ of $>200 \mu \mathrm{g} / \mathrm{bee}$ with negative effects on brood development ${ }^{49}$. In our study, the $\mathrm{LD}_{50}$ for newly emerged worker bees exposed to Envidor was $0.00066 \mu \mathrm{g} /$ bee. Envidor had a high bee mortality rate $(>70 \%)$ in the glass jar test, similar to bees treated with its AI, spirodiclofen. However, Envidor was safe on bees in topical application (13\% mortality). No peer reviewed studies on the toxicity of spirodiclofen to bees or mites were found, but Vandervalk ${ }^{22}$ showed that another tetronic acid, Forbid (spiromesifen $45.20 \%$ ), effectively controlled Varroa mite at higher dilution (10\%) in the glass vial test. Despite the high bee death rate for newly-emerged bees exposed to spirodiclofen, our results indicated a $76-84 \%$ mortality in V. destructor for the AI or FP applications. It is recommended more research on spirodiclofen be conducted to determine an effective dose to kill Varroa mites, and an application method to minimize the negative effects on honey bees. 
Spirotetramat is a systemic miticide used against many crop pests ${ }^{50}$. The contact toxicity on $A$. $c$. indica when spirotetramat was used in the field at 40, 60 and $75 \mathrm{gha}^{-1}$ resulted in $10 \%, 16.67 \%$ and $30 \%$ mortality, respectively, in honey bee populations $s^{51}$. Nevertheless, Maus ${ }^{50}$ concluded that when spirotetramat was applied orally $(107.3 \mu \mathrm{g} /$ bee) and via contact ( $>100 \mu \mathrm{g} / \mathrm{bee}$ ), it remained safe for use on $A$. mellifera. In our study, when adult bees were exposed to either the AI or FP by topical application, spirotetramat did not result in a significant increase in the $24 \mathrm{~h}$ mortality rate $(<12 \%)$. However, a high mortality $(61 \%)$ was observed when bees were exposed to compounds using the surface contact method. When mites were exposed to spirotetramat, $V$. destructor mortality was high (84\%) and similar to the reference control (77\%). Our laboratory results suggest that spirotetramat should be examined as a potential miticide; however, determining an effective dose for controlling Varroa mites in the field, and reducing the negative effect of spirotetramat on honey bees at the colony level, are required.

The standard approach to evaluating the acute toxicity of miticides on Varroa mites or honey bee is to determine the $\mathrm{LD}_{50}$ or $\mathrm{LC}_{50}$ values and the mortality rates a given active ingredient on animals using bioassay techniques. In this project, we described bioassay procedures for screening potential compounds for Varroa control and bee safety. The assays included testing compounds under laboratory conditions for mite and bee mortality using the surface contact (glass vial or glass Mason jar) and topical application (micro-applicator) methods. In the search for alternative synthetic product options to control Varroa mites, the toxicity and mortality values of 17 AIs, 12 of which were evaluated for the first time on Varroa mites and/or honey bees, were determined. Overall, abamectin, acequinocyl, bifenthrin, chlorfenapyr, clofentezine, cyflumetofen, fenpropathrin, hexythiazox, pyridaben, and tolfenpyrad either had limited efficacy against mites, or had high bee mortality. These AIs were not considered for future laboratory field studies as potential Varroa control product.

In conclusion, this research has established initial bioassay procedures for screening potential compounds against Varroa mites. Our results suggest that AIs such as fenazaquin and etoxazole succeeded in controlling Varroa mites under laboratory conditions and are relatively safe for use on honey bees. Fenpyroximate, spirodiclofen, and spirotetramat had relatively high efficiency in mite control, but further investigations are required to mitigate negative effects on A. mellifera. Although laboratory screening of these compounds has proved to be effective against Varroa mites, this is only an initial testing phase, and use of these compounds in colonies is not legal or advised. Further research is required to determine the compound's effects on: colony performance, colony fitness, sub-lethal effects of miticide residues on queens, drones and brood, operator safety, residues in honey and wax, and their safety for human consumption. The next step in the development of an effective miticide would be to conduct more extensive research to assess these compounds under field conditions on full size colonies. We also recommend screening more AIs with different modes of action, and the use of synergists in the bioassay trials, to enhance the efficacy of miticides. Once effective and safe compounds are identified and confirmed at the colony level, the results would support future development of a Varroacide and beekeepers with an additional management tool, thereby adding significant economic value to the beekeeping and agricultural industries.

\section{Methods}

The laboratory trials were conducted at the Crop Diversification Center North (CDCN), Edmonton, Alberta, Canada $\left(53.54^{\circ} \mathrm{N}, 113.49^{\circ} \mathrm{W}\right)$ in summer $2016-2018$. All experimental bee colonies used in this bioassay study were European honey bee $(A$. mellifera) colonies that were managed under the same management practices at $\mathrm{CDCN}$ to reduce variabilities among tested Varroa mite and honey bee populations. The cumulative mortality rates of $V$. destructor and A. mellifera mortality, and the toxicity of 17 Als (abamectin, acequinocyl, amitraz, bifenthrin, chlorfenapyr, clofentezine, cyflumetofen, etoxazole, fenpropathrin, fenpyroximate, fenazaquin, hexythiazox, pyridaben, spirodiclofen, spirotetramat, tebufenpyrad, and tolfenpyrad), and 10 FPs (Apollo, Avid, Capture, Envidor, Fujimite, Kanemite, Kontos, Mitaban, Nealta and Pylon) were tested using surface contact (glass vials and Mason jars) and topical (micro-applicator) methods. In all bioassay tests, if the average of the mite or bee mortality in the negative controls were $>15 \%{ }^{52}$, the samples were discarded and the test repeated.

Chemical preparations. The following commercial FPs were obtained from Terralink, BC, Canada: Avid (abamectin, 1.98\%), Kontos (spirotetramat, 22.4\%), Capture (bifenthrin, 24\%), Pylon (chlorfenapyr, 24\%), Fujimite (fenpyroximate, 5\%), and Envidor (spirodiclofen, 24\%). Other FPs were Nealta (cyflumetofen, 20\%, Bartlett, ON, Canada) and Mitaban (amitraz, 19.9\%, Zoetis, USA). All AIs were obtained from Sigma-Aldrich, ON, Canada, except cyflumetofen (Cedarlane, NC, USA) (Table 1). Acetone (Fisherbrand, Fisher Scientific, Canada) and water were used as solvents for the AIs and FPs, respectively. Acetonitrile (Sigma-Aldrich, USA) was used as solvent for clofentezine. Fresh stock solutions for each FP $\left(100,000 \mathrm{mgL}^{-1}=10 \%\right)$ or AI $(10,000$ $\mathrm{mgL}^{-1}=1 \%$ ) were made in $15 \mathrm{~mL}$ polypropylene centrifuge tubes (Fisherbrand, Fisher Scientific, Canada) using water (density $1 \mathrm{gmL}^{-1}$ ), acetone (density $784 \mathrm{gmL}^{-1}$ ) or acetonitrile (density $786 \mathrm{gmL}^{-1}$ ), respectively. The stock solutions were agitated on a vortex mixer (VWR, USA) for a period of 2-3 min, and prepared for same day use. All interactions with chemicals were done under the fume hood with operators wearing a full-face respirator mask (6900, 3M, USA) including filters (60923, 3M, USA) and other PPE. In laboratory trials, reference controls (Mitaban for FPs and amitraz for AIs), death controls (dimethoate ${ }^{53} 0.000033 \mathrm{mgL}^{-1}$ and amitraz $100,000 \mathrm{mgL}^{-1}$ for bees and mites, respectively), solvent controls (water, acetone and acetonitrile), and negative control (no treatment) served as control treatments.

Mite collection, newly-emerged bees and brood preparation. Two sets of experimental honey bee colonies were provided for this investigation. The first group had high Varroa mite infestation levels ( $>3 \%)$, and were placed in a separate yard without any Varroacide treatment. Every colony in this yard received two drone frames in early July to increase Varroa mite populations for the experiment. The mites from the highly infested colonies were used in the vial experiment and resistance test. The second set of colonies was kept healthy with 
no or low mite levels $(<1 \%)$ in another yard at CDCN. These colonies were used to extract purple-eyed pupae for feeding during the vial test and to supply newly emerged bees for the Mason jar test. The initial arithmetic mean abundance ${ }^{54}$ of Varroa mites in colonies was determined using the alcohol wash method. In this method, a sample of 300 bees was collected in $500 \mathrm{~mL}$ plastic containers filled with $250 \mathrm{~mL}$ of ethanol (70\%), from brood frames sourced from CDCN colonies with high mite infestation $(>3 \%)$. The Varroa-infested bee samples were agitated on an orbital shaker at $300 \mathrm{rpm}$ for $10 \mathrm{~min}$. The number of mites were counted by placing the bee samples in a sieve over a white container. Bees were washed using tap water to dislodge the mites. Mites that fell into the container were counted, and bees were individually counted to calculate mite infestation level. The evaluation of Varroa mite resistance to Apivar took place on the same highly infested colonies before mite collection. An adapted version of the Pettis method ${ }^{55}$ was used to ensure that mites in the experiments were susceptible to amitraz and could be used in the bioassay as a reference control. Using the Pettis method ${ }^{55}$, a group of 150 worker bees were exposed to a piece of Apivar strip $(2.54 \times 6.35 \mathrm{~cm})$ that was stapled on a piece of cardboard and placed in a $500 \mathrm{~mL}$ Mason jar (Bernardin, Canada). The jars with bees were incubated at $25^{\circ} \mathrm{C}$ and $50-60 \%$ $\mathrm{RH}$ in the dark, and the number of dead and live mites were counted $24 \mathrm{~h}$ post-exposure. To collect live Varroa mites for the vial test, 300-500 g Varroa-infested bees from the highly infested colonies were transferred into a Plexiglass shaker basket $(8.5 \times 14 \times 28.5 \mathrm{~cm})$ with a metal mesh bottom $(12.5 \times 27.5 \mathrm{~cm})$. The Plexiglass basket rested inside a Rubbermaid container $(12 \times 20 \times 35 \mathrm{~cm})$ with a fitted lid imbedded with one inlet $\mathrm{CO}_{2}$ valve. The container and bees were agitated at $300 \mathrm{rpm}$ on a mechanical shaker while being exposed to $\mathrm{CO}_{2}\left(5 \mathrm{Lmin}^{-1}\right)$ for $5 \mathrm{~min}$ and another $5 \mathrm{~min}$ without $\mathrm{CO}_{2}$. Mites that fell through the mesh onto the bottom of the container were collected with a fine-tipped paintbrush and placed in Petri dishes lined with a moist paper towel to prevent desiccation of the live mites ${ }^{56}$. Capped brood frames were taken from healthy colonies ( $<1 \%$ mite infestation) to provide fresh pupae to sustain mites during the vial experiment. Purple-eyed pupae were carefully removed from cells using forceps and placed on a damp paper towel in a Petri dish with a cover and incubated at $33 \pm 1{ }^{\circ} \mathrm{C}$ and $60 \pm 5 \% \mathrm{RH}$ in the dark until required for experiment. In order to collect newly-emerged bees for the Mason jar test, frames of sealed brood free of worker bees were removed from healthy colonies and individually confined in wooden brood emergence cages $(50 \times 26 \times 7 \mathrm{~cm})$. Each emergence cage had a screen on both sides for ventilation and was kept in an incubator at $33 \pm 1{ }^{\circ} \mathrm{C}$ and $60 \pm 5 \% \mathrm{RH}$ in the dark until bees emerged. Once emerged, the bees were collected in a plastic Rubbermaid container and exposed to $\mathrm{CO}_{2}$ for handling.

Acute surface contact toxicity assay of miticides on Varroa mites (Vial test). Subsequent serial dilutions of $10,000 \mathrm{mgL}^{-1}, 1000 \mathrm{mgL}^{-1}, 100 \mathrm{mgL}^{-1}, 10 \mathrm{mgL}^{-1}, 1 \mathrm{mgL}^{-1}$ and $0.1 \mathrm{mgL}^{-1}$ were prepared in $15 \mathrm{~mL}$ polypropylene centrifuge tubes for AIs $(n=17)$ or FPs $(n=10)$. Borosilicate scintillation glass vials $(20 \mathrm{~mL}$, ColePalmer, QC, Canada) were treated with $0.5 \mathrm{~mL}$ of each dilution using a pipette, and each dilution had four replicates per compound. The glass vials were rotated horizontally on a hot dog roller (Addcraft, Hicksville, NY, USA) under a fume hood at room temperature for 2-3 h until solvents completely evaporated and the residue of the compounds homogenously coated the inner side-surface of vials $\left(40.36 \mathrm{~cm}^{2}\right)$. To do this, the hot dog roller functioned normally without any modifications, except the heating element was turned off. Eight to ten live and freshly collected mites were placed into the treated vials using a new-labelled brush (Regular size Ultrabrush, Microbrash, WI, USA). To avoid cross-contamination, a new brush was used for each dilution of chemicals. Prepared vials with mites were incubated (She Lab, Sheldon Inc., OR, USA) at $33 \pm 1{ }^{\circ} \mathrm{C}$ and $60 \pm 5 \% \mathrm{RH}$ in the dark. The temperature $\left({ }^{\circ} \mathrm{C}\right)$ and relative humidity (\%) in incubator were monitored using $\mathrm{HOBO}$ (Onset Computer Corporation, MA, USA) data loggers. Mite mortality was counted after $4 \mathrm{~h}$ of exposure and the surviving mites were transferred into a clean polypropylene $2 \mathrm{~mL}$ centrifuge tube (Fisherbrand, Fisher Scientific, Canada) with holes poked on top for ventilation. Each tube contained one honey bee purple-eyed pupa for feeding. Tubes were incubated at $33 \pm 1{ }^{\circ} \mathrm{C}$ and $60 \pm 5 \% \mathrm{RH}$ in the dark for an additional $20 \mathrm{~h}$. Mite mortality was determined $24 \mathrm{~h}$ post-treatment by transferring them into a Petri dish. Mortality was assessed by gently probing mites using a fine-tipped paint brush under a magnifying glass to detect subtle limb movement. Mites that were completely motionless (i.e. lack of appendage movement), while probing were considered dead. Control treatments included three solvents (acetone, acetonitrile and water), two reference controls (amitraz and Mitaban) and a negative control (no treatment).

Acute topical toxicity assay of miticides on Varroa mites (micro-applicator test). A digital Nano-pump (KDS310,Cole-Parmeer, IL, USA) fitted with a $10 \mu \mathrm{L}$ micro-syringe (701RN, Hamilton Company, NV, USA) and small hub needle ( $22 \mathrm{~s}$ gauge, 0.75 in, point style 3, Hamilton, Company, NV, USA) was used to apply candidate compounds onto mites. For each compound of AIs $(n=17), 8$ to 10 live and freshly collected mites were topically treated with $0.15 \mu \mathrm{L}$ on the dorsal shield to receive $0.0000117 \mu \mathrm{g} / \mathrm{mite}, 0.000117 \mu \mathrm{g} / \mathrm{mite}$, $0.00117 \mu \mathrm{g} / \mathrm{mite}, 0.0117 \mu \mathrm{g} / \mathrm{mite}, 0.117 \mu \mathrm{g} / \mathrm{mite}$, or $1.17 \mu \mathrm{g} / \mathrm{mite}$, with four replicates for each dilution. Treated mites were placed directly into $2 \mathrm{~mL}$ polypropylene centrifuge tubes containing one purple-eyed pupa for feeding using a new-labelled micro brush for each dilution. Tubes were incubated at $33 \pm 1{ }^{\circ} \mathrm{C}$ and $60 \pm 5 \% \mathrm{RH}$ in the dark for $24 \mathrm{~h}$. Mite mortality was assessed at $24 \mathrm{~h}$ post-treatment. Control treatments included three solvents (acetone, acetonitrile and water), a positive control (amitraz) and a negative control (no treatment).

Acute surface contact toxicity assay of miticides on honey bees (Mason jar test). The acute surface contact toxicity of compounds for honey bees were evaluated using Mason jars (60 mL, Uline, AB, Canada). Using a pipette, mason jars were treated with $0.5 \mathrm{~mL}$ of each chemical dilution for the AIs $(\mathrm{n}=17)$ or FPs $(\mathrm{n}=10)\left(0.1 \mathrm{mgL}^{-1}, 1 \mathrm{mgL}^{-1}, 10 \mathrm{mgL}^{-1}, 100 \mathrm{mgL}^{-1}, 1000 \mathrm{mgL}^{-1}\right.$ or $\left.10,000 \mathrm{mgL}^{-1}\right)$ with four replicates per dilution per compound. The Mason jars were horizontally rotated on a hot dog roller, like the glass vials, under a fume hood at room temperature for 2-3 h until solvents completely evaporated and the residue of compounds 
homogenously to coated the inside surface of the jars $\left(67.75 \mathrm{~cm}^{2}\right)$. To do this, the hot dog roller functioned normally without any modifications, except the heating element was turned off. One sugar cube was glued to the inside-bottom of the jar before 10 newly emerged bees were added. The top of the jar was covered using a fine mesh screen (16 mesh, Easy Screen, RCR International Inc., Canada) that was secured using an elastic band. The bees were incubated at $33 \pm 1{ }^{\circ} \mathrm{C}$ and $60 \pm 5 \% \mathrm{RH}$ in the dark for $24 \mathrm{~h}$. After $24 \mathrm{~h}$ exposure treatment, bee mortality was assessed. Bees were determined to be dead if they were completely motionless (i.e. no body or appendage movement), when the jar was slightly agitated. Control treatments included three solvents (acetone, acetonitrile and water), two positive control (amitraz and Mitaban) and a negative control (no treatment).

Acute topical toxicity assay of miticides on honey bees (micro-applicator test). Using the same methodology for topically treating Varroa mites, the micro-applicator was fitted with a $25 \mu \mathrm{L}$ micro-syringe $(702 \mathrm{RN})$ and small hub needle ( $22 \mathrm{~s}$ gauge, $0.75 \mathrm{in}$, point style 3$)$ to apply each candidate compound. For dilutions of AIs $(\mathrm{n}=17)$ or FPs $(\mathrm{n}=10)(0.000078 \mu \mathrm{g} / \mathrm{bee}, 0.00078 \mu \mathrm{g} / \mathrm{bee}, 0.0078 \mu \mathrm{g} / \mathrm{bee}, 0.078 \mu \mathrm{g} / \mathrm{bee}, 0.78 \mu \mathrm{g} / \mathrm{bee}$, or $7.8 \mu \mathrm{g} / \mathrm{bee}$ ), a group of 20 newly emerged worker bees were anesthetized by exposure to $\mathrm{CO}_{2}$ and individual bees were topically treated with $1 \mu \mathrm{L}$ of the each compound dilution applied to the thorax. Each treatment had four replicates. Once treated, the bees were placed in $125 \mathrm{~mL}$ plastic containers (Plastipak Industries Inc., SK, Canada) and fed one sugar cube. Holes were made on the body of container for air ventilation. The bees were incubated at $33 \pm 1{ }^{\circ} \mathrm{C}$ and $60 \pm 5 \% \mathrm{RH}$ in the dark for $24 \mathrm{~h}$. Bee mortality was assessed $24 \mathrm{~h}$ post exposure. Bees were determined to be dead if they were completely motionless (i.e. no body or appendage movement), when the container was slightly agitated. Control treatments included three solvents (acetone, acetonitrile and water), two positive controls (amitraz and Mitaban) and a negative control (no treatment).

Statistical analysis. The variables for cumulative mite and bee mortality rate (\%) were analyzed using a mixed model ANOVA (PROC MIXED) ${ }^{57}$ in which compounds were treated as main plots, dilutions as sub plots and replicates as random effects. The cumulative mortality was estimated as a proportion of dead mites or dead bees in all replicates of dilutions in each compound. Normality of the data was analyzed using Shapiro-Wilk test (PROC UNIVARIATE) ${ }^{57}$. Proportion for cumulative mortality rates in all trials were arcsine transformed prior to analyses ${ }^{58}$. Data are presented as untransformed means. Where significant interactions occurred, differences among treatment means were compared using the Bonferroni correction. The lethal concentration fifty $\left(\mathrm{LC}_{50}\right)$ and lethal dose fifty $\left(\mathrm{LD}_{50}\right)$ of compounds to V. destructor and A. mellifera at $24 \mathrm{~h}$ were evaluated using PROC PROBIT $^{57}$. The percentage of mite mortality was corrected using Abbott's correction ${ }^{29}$ as corrected mortality $(\%)=(\%$ mortality in treatment $-\%$ mortality in control $) /(100-\%$ mortality in control). The toxicity ratios (AI $\mathrm{LC}_{50} /$ amitraz $\left.\mathrm{LC}_{50}\right)$ and selectivity ratios $\left(A\right.$. mellifera $\mathrm{LC}_{50} / V$. destructor $\left.\mathrm{LC}_{50}\right)$ at $24 \mathrm{~h}$ post exposure were determined. If confidence intervals (CI) overlapped, the difference between toxicity values were evaluated as not statistically significant.

Received: 11 September 2020; Accepted: 25 November 2020

Published online: 09 December 2020

\section{References}

1. Currie, R. W., Pernal, S. F. \& Guzman-Novoa, E. Honey bee colony losses in Canada. J. Apicult. Res. 49(1), 104-106 (2010).

2. van Engelsdorp, D., Hayes, J., Underwood, R. \& Pettis, J. S. A survey of honey bee losses in the United States, fall 2008 to spring 2009. J. Apicult. Res. 49(1), 7-14 (2010).

3. LeConte, Y., Ellis, M. \& Ritter, W. Varroa mites and honey bee health: can Varroa explain part of the colony losses?. Apidologie 41(3), 353-363 (2010).

4. Higes, M. et al. How natural infection by Nosema ceranae causes honeybee colony collapse. Environ. Microbiol. 10(10), 2659-2669 (2008).

5. Carreck, N. \& Neumann, P. Honey bee colony losses. J. Apicult. Res. 49(1), 1-6 (2010).

6. Di Passquale, G. et al. Influence of pollen nutrition on honey bee health: do pollen quality and diversity matter?. PLoS ONE 8(8), e72016 (2013).

7. Wu, J. Y., Anelli, C. M. \& Sheppard, W. S. Sub-lethal effects of pesticides residues in brood comb on worker honey bee (Apis mellifera) development and longevity. PLoS ONE 6(2), e14720 (2011).

8. Rosenkranz, P., Aumeier, P. \& Ziegelmann, B. Biology and control of Varroa destructor. J. Invertbr. Pathol. 103, s96-s119 (2010).

9. Ramsey, S. D. et al. Varroa destructor feeds primarily on honey bee fat body tissue and not hemolymph. PNAS 116(5), 1792-1801 (2019).

10. Nasr, M. E. \& Kevan, P. G. Diseases and parasites, eradication or management: what strategy for honey bee health?. Bee World 80(2), 53-54 (1999).

11. Martel, A. C. et al. Acaricide residues in honey and wax after treatment of honey bee colonies with Apivar or Asuntol 50. Apidologie 38, 534-544 (2007).

12. Rinkevich, F. Detection of amitraz resistance and reduced treatment efficacy in the Varroa mite, Varroa destructor, within commercial beekeeping operations. PLoS ONE 15(1), e0227264 (2020).

13. Agrebi, N. E. et al. Pesticide and veterinary drug residues in Belgian beeswax: occurrence, toxicity, and risk to honey bees. Sci. Total Environ. 745(25), 1-14 (2020).

14. Plapp, F. W., McWhorter, G. M. \& Vance, W. H. Monitoring for pyrethroids resistance in the tobacco bud worm in Texas-1986. In Proc. Beltwide Cotton Production Research Conference, Dallas, TX (ed. Nelson, T. C.) 324-326 (National Cotton Council, Memphis, 1987).

15. Hoffmann, A. A., Porter, S. \& Kovacs, I. The response of the major crop and pasture pest, the red-legged earth mite (Halotydeus destructor) to pesticides: dose-response cure and evidence for tolerance. Exp. Appl. Acarol. 21, 151-162 (1997).

16. Latheef, M. A. \& Hoffmann, W. C. Toxicity of selected acaricides in a glass-vial bioassay to two spotted spider mite (Acari: Tetranychidae). Southwest. Entomol. 39, 29-36 (2014). 
17. Prabhaker, N., Toscano, N. C., Henneberry, T. J., Castle, S. J. \& Weddle, D. Assessment of two bioassay techniques for resistance monitoring of silverleaf whitefly (Homoptera: Aleyrodidae) in California. J. Econ. Entomol. 89, 805-815 (1996).

18. Willrich, M., Leonard, B. \& Cook, D. Laboratory and field evaluation of insecticide toxicity to stink bugs (Heteroptera: Pentatomidae). J. Cotton Sci. 7, 156-163 (2003).

19. Lopez, J. D. Jr. et al. Evaluation of toxicity of selected insecticides against thrips on cotton in laboratory bioassays. J. Cotton Sci. 12, 188-194 (2008).

20. Kanga, L. H. B., Adamczyk, J., Marshall, K. \& Cox, R. Monitoring for resistance to organophosphorus and pyrethroid insecticides in Varroa mite population. J. Econ. Entomol. 103, 1797-1802 (2010).

21. Kamler, M., Nesvorna, M., Stara, J., Erban, T. \& Hubert, J. Comparison of tau-fluvalinate, acrinathrin, and amitraz effects on susceptible and resistant populations of Varroa destructor in a vial test. Exp. Appl. Acarol. 69, 1-9 (2016).

22. Vandervalk, L. New options for integrated pets management of Varroa destructor (Acari: Varroidae) in colonies of Apis mellifera (Hymenoptera: Apidae) under Canadian prairie conditions. M.SC. Thesis. University of Alberta, 121 (2013).

23. Elzen, P. J., Eischen, F. A., Baxter, J. R., Elzen, G. W. \& Wilson, W. T. Detection of resistance in US Varroa jacobsoniOud. (Mesostigmata: Varroidae) to the acaricide fluvalinate. Apidologie 30, 12-17 (1999).

24. Ali, M. A., Macedo, P. A. \& Ellis, M. D. Evaluation of three concentrations of tebufenpyrad for the control of Varroa destructor (Acari: Varroidae). J. Econ. Entomol. 96(2), 259-263 (2003).

25. Dahlgren, L., Johnson, R. M., Siegfried, B. D. \& Ellis, M. D. Comparative toxicity of acaricides to honey bee (Hymenoptera: Apidae) workers and queens. J. Econ. Entomol. 105(6), 1895-1902 (2012).

26. Leite, D. T. et al. Toxicity of fenpyroximate, difenoconazole and mineral oil on Apis mellifera L.. Sociobiology 65(4), 737-743 (2018).

27. Ziegelmann, B. et al. Lithium chloride effectively kills the honey bee parasite Varroa destructor by a systemic mode of action. Sci. Rep. 8, 1-9 (2018).

28. Maggi, M. D., Ruffinengo, S. R., Gende, L. B., Eguaras, M. J. \& Sardella, N. H. LC ${ }_{50}$ baseline levels of amitraz, coumaphos, fluvalinate and flumethrin in populations of Varroa destructor from Buenos Aires Province, Argentina. J. Apicult. Res. 47, 292-295 (2008).

29. Abbot, W. S. A method of computing the effectiveness of an insecticide. J. Econ. Entomol. 18, 265-267 (1925).

30. Santiago, G. P., Otero-Colina, G., Sanchez, D. M., Guzman, M. E. R. \& Vandame, R. Comparing effects of three acaricides on Varroa jacobsoni (Acari: Varroidae) and Apis mellifera (Hymenoptera: Apidae) using two application techniques. Florida Entomol. 83, 468-476 (2000).

31. Abed, T. \& de Lahitte, J. D. Determination of $\mathrm{LD}_{50}$ of amitraz and coumaphos on Varroa jacobsoni Oud by means of anti-varroa (Schering) and Perizin (Bayer) acaricides. Apidologie 24(2), 121-128 (1993).

32. Elzen, P. J., Baxter, J. R., Spivak, M. \& Wilson, W. T. Control of Varroa jacobsoniOud. resistant to fluvalinate and amitraz using coumaphos. Apidologie 31, 437-441 (2000).

33. Rodriguez-Dehaibes, S. R., Otero-Colina, G., Sedas, V. P. \& Jimenez, J. A. V. Resistance to amitraz and flumethrin in Varroa destructor populations from Veracruz, Mexico. J. Apicult. Res. 44, 124-125 (2005).

34. Zhu, W., Schmehl, D. R., Mullin, C. A. \& Frazier, J. L. Four common pesticides, their mixtures and a formulation solvent in the hive environment have high oral toxicity to honey bee larvae. PLoS ONE 9(1), e77547 (2014).

35. Lindberg, C. M., Melathopoulos, A. P. \& Winston, M. L. Laboratory evaluation of miticides to control Varroa jacobsoni (Acari: Varroidae), a honey bee (Hymenoptera: Apidae) parasite. J. Econ. Entomol. 93, 189-198 (2000).

36. Mao, W., Schuler, M. \& Berenbaum, M. CYP9Q-mediated detoxification of acaricides in the honey bee (Apis mellifera). PNAS 108, 12657-12662 (2011).

37. Johnson, R. M., Dahlgren, L., Siegfried, B. D. \& Ellis, M. D. Acaricide, fungicide and drug interactions in honey bees (Apis mellifera). PLoS ONE 8, e54092 (2013).

38. Ulziibayar, D. \& Jung, C. Comparison of acute toxicity of different groups of pesticides to honey bee workers (Apis mellifera L.). J. Apicult. Res. 34(4), 305-313 (2019).

39. Hillier, N. K. \& Fros, E. H. Fate of dermally applied miticides fluvalinate and amitraz within honey bee (Hymenoptera: Apidae) bodies. J. Econ. Entomol. 106(2), 558-565 (2013).

40. Dekeyser, M. A. Acaricide mode of action. Pest Manage. Sci. 61, 103-110 (2005).

41. Suzuki, J. et al. Synthesis and activity of novel acaricidal/insecticidal 2,4-diphenyl-1,3-oxazolines Nihon Noyaku Gakkaishi. J. Pestic. Sci. 27, 1-8 (2002).

42. Longhurst, C. et al. Fenazaquin, novel acaricide for the management of spider mites in a variety of crops. in Proc. Brighton Crop Prot. Conf. Pests Dis., BCPC, Farnham, Surrey, UK, 51-58 (1992).

43. Dutton, R., Leonard, P. \& Brow, K. C. Fenazaquin-a new, selective acaricide for use in fruit crops. Med. Fac. Landbouw Univ. Gent 58(2b), 485-490 (1993).

44. Yeshwanth, H. M., Residual toxicity of some new insecticides to honey bee, Apis cerana indica F. (Hymenoptera: Apidae), M.Sc. Thesis, University of Agricultural Sciences Gkvk, Bangalore (2007).

45. Kimura, M., Konno, T. \& Kajiwara, O. Synergistic acaricidal compositions containing pyrazole oxime and esterase, Japanese Patent JP 02300103 (1990).

46. Johnson, R. M., Ellis, M. D., Mullin, C. A. \& Frazier, M. Pesticides and honey bee toxicity-USA. Apidologie 41, 312-331 (2010).

47. Li-Byarlay, H., Rittschof, C. C., Massey, G. H., Pittendrigh, B. R. \& Robinson, G. E. Socially responsive effects of brain oxidative metabolism on aggression. PNAS 111(34), 12533-12537 (2014).

48. Kim, Y. J., Lee, S. H., Lee, S. W. \& Ahn, Y. J. Fenpyroximate resistance in Tetranychus urticae (Acari: Tetranychidae): cross-resistance and biochemical resistance mechanisms. Pest Manage. Sci. 60, 1001-1006 (2004).

49. Sverdrup, L. E. et al. Risk Assessment of the Pesticide Envidor with the Active Substance Spirodiclofen (Norwegian Scientific Committee for Food Safety, Oslo, 2011).

50. Maus, Ch. Ecotoxicological profile of the insecticide spirotetramat. Bayer Crop Sci. J. 61(2), 159-180 (2008).

51. Vinothkumar, B., Kumaran, N., Boomathi, N., Saravanan, P. A. \& Kuttalam, S. Toxicity of spirotetramat 150 OD to honey bees. Madras Agric. J. 97(1-3), 86-87 (2010).

52. OECD. Guideline 214: Honeybees, Acute Contact Toxicity Test. OECD Guidelines for the Testing of Chemicals, Section 2 (OEDC Publishing, Paris, 1998).

53. Gough, H. J., McIndoe, E. C. \& Lewis, B. G. The use of dimethoate as a reference compound in laboratory acute toxicity tests on honey bees (Apis mellifera L.) 1981-1992. J. Apicult. Res. 33, 119-125 (1994).

54. Rozsa, L., Reiczigel, J. \& Majoros, G. Quantifying parasites in samples of hosts. J. Parasitol. 86, 228-232 (2000).

55. Pettis, J. S., Shimanuki, H. \& Feldlaufer, M. R. An assay to detect fluvalinate resistance in Varroa mites. Am. Bee J. 138, 538-541 (1998).

56. Bahreini, R. \& Currie, R. W. Influence of honey bee genotype and wintering method on wintering performance of Varroa destructor (Parasitiformes: Varroidae)-infected honey bee (Hymenoptera: Apidae) colonies in a Northern climate. J. Econ. Entomol. 132, 57-65 (2015).

57. SAS Institute Inc. SAS/STATVR 9.3 User's Guide (SAS Institute Inc., Cary, 2012).

58. Snedecor, G. W. \& Cochran, W. G. Statistical Methods (The Iowa State University Press, Iowa, 1980). 


\section{Acknowledgements}

We thank Rosanna Punko, Parisa Fatehmanesh, Maksat Igdyrov, Michelle Fraser, Mellissa Howard, Alexandra Panasiuk, Lynae Ovinge, Jeff Kearns, and Glyn Stephens. We also appreciate Dr. Shelley Hoover for her support. This research was funded in part by grants from the Alberta Crop Industry Development Fund (ACIDF), Growing Forward 2 (a federal-provincial -territorial initiative) and the Alberta Beekeepers Commission (ABC). This research was sponsored by acknowledged funders. The funders had no role in the study design, data collection and analyses, and preparation of the manuscript or publishing.

\section{Author contributions}

M.N. conceived the project. R.B. and M.N. prepared the experimental design. D.F. supervised the project. Laboratory trials and samples collection were performed by R.B., C.D., O.D. and S.M. Statistical analyses were carried out by R.B. and M.N. Manuscript draft was wrote by R.B., C.D. and M.N. All authors read and approved the manuscript.

\section{Competing interests}

The authors declare no competing interests.

\section{Additional information}

Supplementary Information The online version contains supplementary material available at https://doi. org/10.1038/s41598-020-78561-2.

Correspondence and requests for materials should be addressed to R.B.

Reprints and permissions information is available at www.nature.com/reprints.

Publisher's note Springer Nature remains neutral with regard to jurisdictional claims in published maps and institutional affiliations.

(c) (i) Open Access This article is licensed under a Creative Commons Attribution 4.0 International License, which permits use, sharing, adaptation, distribution and reproduction in any medium or format, as long as you give appropriate credit to the original author(s) and the source, provide a link to the Creative Commons licence, and indicate if changes were made. The images or other third party material in this article are included in the article's Creative Commons licence, unless indicated otherwise in a credit line to the material. If material is not included in the article's Creative Commons licence and your intended use is not permitted by statutory regulation or exceeds the permitted use, you will need to obtain permission directly from the copyright holder. To view a copy of this licence, visit http://creativecommons.org/licenses/by/4.0/.

(C) Crown 2020 